University of Louisville

ThinkIR: The University of Louisville's Institutional Repository

Electronic Theses and Dissertations

$12-2004$

\title{
Louise C. Morel, The Louisville Women's City Club, and municipal housekeeping in Louisville, 1917-1935.
}

Gail Elizabeth Chooljian Nall

University of Louisville

Follow this and additional works at: https://ir.library.louisville.edu/etd

\section{Recommended Citation}

Nall, Gail Elizabeth Chooljian, "Louise C. Morel, The Louisville Women's City Club, and municipal housekeeping in Louisville, 1917-1935." (2004). Electronic Theses and Dissertations. Paper 1038. https://doi.org/10.18297/etd/1038

This Master's Thesis is brought to you for free and open access by ThinkIR: The University of Louisville's Institutional Repository. It has been accepted for inclusion in Electronic Theses and Dissertations by an authorized administrator of ThinkIR: The University of Louisville's Institutional Repository. This title appears here courtesy of the author, who has retained all other copyrights. For more information, please contact thinkir@louisville.edu. 
Louise C. Morel, the Louisville Women's City Club, and Municipal Housekeeping in Louisville, 1917-1935

\title{
By
}

\section{Gail Elizabeth Chooljian Nall}

B.A., Bellarmine University, 2001

\author{
A Thesis \\ Submitted to the Faculty of the \\ Graduate School of the University of Louisville \\ in Partial Fulfillment of the Requirements \\ for the Degree of
}

\author{
Master of Arts
}

\begin{abstract}
Department of History University of Louisville Louisville, Kentucky
\end{abstract}

December 2004 
Louise C. Morel, the Louisville Women's City Club, and Municipal Housekeeping in Louisville, 1917-1935

By

Gail Elizabeth Chooljian Nall

B.A., Bellarmine University, 2001

A Thesis Approved on

December 13, 2004

by the following Thesis Committee:

Thesis Director 


\section{DEDICATION}

This thesis is dedicated to my husband, Michael Nall, for his constant love and support, to my father, James Chooljian, for his enthusiasm and praise, and to my mother, Judith Mize, for both telling me and showing me that I can do anything. 


\section{ACKNOWLEDGMENTS}

I would like to thank my thesis advisor, Dr. Nancy Theriot, for all her help and unending patience. Also, I would like to thank the other two members of my thesis committee, Dr. Ann T. Allen and Dr. John Cumbler, for their interest in my thesis and their insights. Rita Hettinger and Lee Keeling have also been invaluable in this process, both for their encouragement and for their help with paperwork and other necessities.

I owe thanks to the Kentucky Federation of Women's Clubs, and especially to Barbara Davis, Donna Short, and Jan Suter, for giving me an internship and allowing me access to the archives. I also need to thank my employers for their flexibility throughout this process: Claudette Sylvester, the University of Louisville History Department and Dr. Bruce Adams, Dr. Ann T. Allen, the Filson Historical Society, and Foley, Bryant, and Holloway.

Finally, I could not have accomplished this thesis without the support of my friends and family: Michael S. Nall, James Chooljian, Judith and Joel Mize, Cheryl Chooljian, Mike and Joann Nall, Lisa and David Pisterman, Whitney Powell, Jennifer Cole, Frances Adams, Matt Church, Beth Rakel, Natalie Stroupe, Kelly Wade, and everyone else who kindly listened to stories about Louise Morel and the Louisville Women’s City Club. 


\section{ABSTRACT \\ LOUISE C. MOREL, THE LOUISVILLE WOMEN'S CITY CLUB, AND MUNICIPAL HOUSEKEEPING IN LOUISVILLE, 1917-1935 \\ Gail Elizabeth Chooljian Nall}

December 13, 2004

Louise C. Morel was a leading social reformer in Louisville from 1917 through the early 1940s. Morel's work is a primary example of the continuation of Progressive Era ideals into the decades after the traditional end of the Progressive Era. Because the areas in which she worked were those that had traditionally appealed to and benefited women and children, Morel became known as a municipal housekeeper. With the help of fellow members of the Louisville Women’s City Club, Morel conducted numerous surveys, organized conventions to educate the public, gave speeches, and urged city leaders to institute reforms in various areas. The issues in which Morel was interested include tuberculosis, garbage separation and disposal, housing quality, sewer expansion, and improvement of public buildings and outdoor areas. Morel’s work influenced women both in Louisville and across the state, and left a lasting imprint on the city. 
TABLE OF CONTENTS

PAGE

ACKNOWLEDGMENTS ............................................... iv

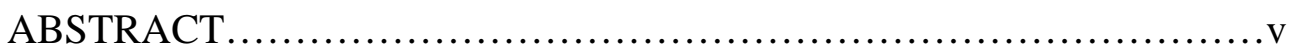

CHAPTER ONE: INTRODUCTION.................................

CHAPTER TWO: THE NATIONAL REFORM MOVEMENT AND

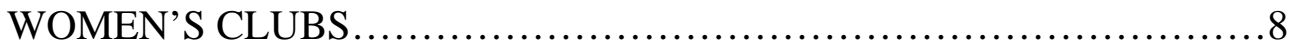

CHAPTER THREE: LOUISE MOREL AND THE LOUISVILLE

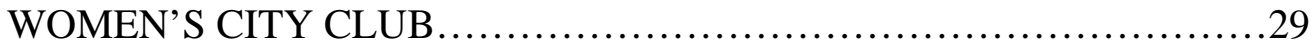

CHAPTER FOUR: THE 1918 GARBAGE DISPOSAL AND

COLLECTIONS SURVEY, THE 1920 SANITARTY SURVEY, AND

SEWER IMPROVEMENT................................................

CHAPTER FIVE: THE 1922 HEALTH EXPOSITION, THE 1924

HOUSING SURVEY, AND TUBERCULOSIS HOSPITALS..............58

CHAPTER SIX: BETTER HOMES IN AMERICA, 1924-1935; THE 1934 HOUSING SURVEY; AND THE CLEANLINESS SURVEY

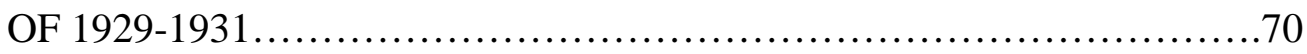

CHAPTER SEVEN: CONCLUSION......................................

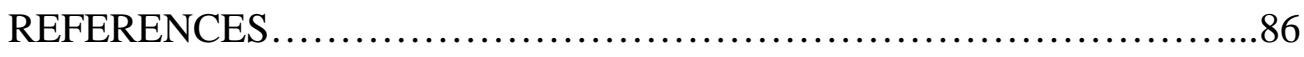

APPENDIX I: PHOTOGRAPHS AND DOCUMENTS.....................95

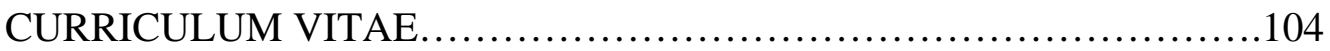




\section{CHAPTER ONE}

\section{INTRODUCTION}

During the later years of the nineteenth century and the earlier decades of the twentieth century (known as the Progressive Era), the population in United States cities increased rapidly. This population increase caused stress on city services and buildings, and overcrowded buildings and public institutions. City dwellers noticed these problems, and many became alarmed by their sudden proliferation. In response, concerned middle class and upper middle class men and women urged city reforms. White, middle-class women especially sought to fix the day-to-day problems of the cities. They hoped to improve the methods of garbage collection and elimination. They worked for prevention of tuberculosis and other communicable diseases and for the care of those who suffered from them. Reform-minded women wanted to end construction of low-quality housing. They sought to reduce crowding and to implement safety measures in schools, theaters, parks, and factories. They also campaigned for bonds to expand undersized sewer systems. All of these problems_-garbage, disease, housing, public safety, sewers, and many other issues-were genuine concerns among city reformers in the early decades of the twentieth century. Some of the most influential solutions for dealing with these problems came from women, and more specifically from those involved in reformoriented women's clubs. 
Historical analysis of the Progressive Era suggests the city reform movement began its decline with the United States’ entry into World War I in 1917 and diminished even further a few years later after the passage of the Nineteenth Amendment, which granted women the right to vote. Most historians propose that World War I drew women reformers' focus away from the mundane issues of city life and toward the global issues of war and peace, and that the right to vote offered women a different way in which to exercise their concerns. ${ }^{1}$ While it was no longer the center of the country's focus, the city reform movement remained a vital part of many city women’s lives. Reform work continued on a national level, albeit more quietly than it had operated before the 1920s, and women participated in reform activities in their cities. In Louisville, Louise Morel and the Louisville Women's City Club did not begin their work until the "end" of the Progressive Era. Morel and the City Club are primary examples of the continued existence of reform work in the United States after 1917. Morel based her work on Progressive ideals and remained an outspoken city reformer in Louisville for more than two decades.

Within the Louisville Women’s City Club, Louise Charlotte Morel was the most vocal reformer. A member of the club from its inception in 1917, Morel’s involvement continued to grow over the next two and a half decades after the generally accepted end of the Progressive movement. At first, Morel only took part in club-directed reform

\footnotetext{
${ }^{1}$ For arguments about the "end" of the Progressive Era as it affected women reformers, see Suzanne Lebsock, "Women and American Politics, 1880-1920" in Women, Politics, and Change, ed. by Louise A. Tilly and Patricia Gurin (New York: The Russell Sage Foundation, 1990), 35-62; Karen Blair, The Clubwoman as Feminist: True Womanhood Redefined (New York: Holmes and Meier Publishers, 1980); Allen F. Davis, Spearheads for Reform: The Social Settlements and the Progressive Movement, 1890-1914 (New York: Oxford U. Press, 1967); Clarke Chambers, Seedtime of Reform: American Social Service and Social Action, 1918-1933 (Minneapolis: U. of Minnesota Press, 1963); and various articles in Noralee Frankel and Nancy S. Dye, eds., Gender, Class, Race, and Reform in the Progressive Era (Lexington, KY: The University Press of Kentucky, 1991).
} 
activities, but she quickly became the force behind a majority of the club's work in cleaning and bettering the city. By the mid-1920s, Morel had joined several other city and national organizations, was working in conjunction with city departments, and began to use the City Club as a means to promote the work and complete the goals of these other organizations. Morel's influence spread to all women's clubs in Kentucky when clubwomen elected her chairwoman of the Kentucky Federation of Women's Clubs' (KFWC) Public Health Department in the 1920s. Later, she gained a national audience for her ideas when Morel became the Public Health chair for the General Federation of Women’s Clubs (GFWC) during the early 1940s.

Morel employed various methods in pushing for reforms, including social surveys. Using surveys allowed Morel and the clubwomen to cover the entire city in sections. The surveys' purpose was to expose unhealthy and unsafe conditions related to the topic of the individual survey. Through exposing substandard conditions, Morel hoped to raise public consciousness and to get the city to take action. Depending upon the survey, women from the City Club, other women's clubs, members of city organizations, or volunteers from various other groups participated in conducting the surveys. Morel also used other means to promote city reform including campaigning for bonds to pay for improved city services; meeting with and writing to city, state, and national government leaders; educating and motivating other women to get involved in health and sanitation issues through lectures; and educating the general public on sanitation laws, ways to prevent diseases, and other city problems through lectures and conventions. ${ }^{2}$

\footnotetext{
${ }^{2}$ See the Louise C. Morel Papers, Kentucky Federation of Women’s Clubs Archives, Louisville, KY; and the Louisville Women's City Club Papers (uncatalogued), Filson Historical Society, Louisville, KY.
} 
These methods were not unique to Morel and the City Club. Social reformers, both women and men, throughout the country (but especially in the larger cities of the Northeast and Midwest United States) also made use of surveys, campaigning, lecturing, and holding conventions in their work for reform. ${ }^{3}$ These strategies, and the types of social problems they sought to expose and fix, especially appealed to educated middle class women. Reform-minded women formed a large part of the Progressive movement and continuing service work in the 1920s and 1930s. ${ }^{4}$

The Progressive movement encompassed a number of reforms, some of which were almost exclusive to one gender, while others involved both men and women. The reforms Morel and the City Club were most interested in-preventing the spread of disease, eliminating slum areas, improving garbage pick-up service, ensuring the safety and cleanliness of public places_comprised a uniquely female-only branch of the Progressive movement known as “municipal housekeeping.” Primarily concerned with the literal "cleaning up" of the city, municipal housekeepers used their home housekeeping skills to make the city more like a larger version of the ideal home. Municipal housekeeping also served as a way for white, middle-class women to extend

\footnotetext{
${ }^{3}$ For information about reform methods, see: Michael Gordon, "The Social Survey Movement and Sociology in the United States," Social Problems 21 (Fall 1973): 284-298; Lebsock, "Women and American Politics, 1880-1920”; Davis, Spearheads for Reform; Blair, The Clubwoman as Feminist; Maureen Flanagan, "Gender and Urban Reform: The City Club and the Women's City Club of Chicago in the Progressive Era," The American Historical Review 95 (Oct. 1990): 1032-1050; Marlene Stein Wortman, "Domesticating the Nineteenth-Century American City," Prospects: An Annual of American Cultural Studies, 3 (1977): 531-572; and various articles in Frankel and Dye, eds., Gender, Class, Race, and Reform in the Progressive Era.

${ }^{4}$ For an analysis of women's work in Progressive reform, see: Lebsock, "Women and American Politics, 1880-1920; Blair, The Clubwoman as Feminist; Davis, Spearheads for Reform; Wortman, "Domesticating the Nineteenth-Century American City"; Frankel and Dye, eds., Gender, Class, Race, and Reform in the Progressive Era; Darlene Clark Hine, "We Specialize in the Wholly Impossible: The Philanthropic Work of Black Women” in Lady Bountiful Revisited: Women, Philanthropy, and Power, ed. by Kathleen D. McCarthy (New Brunswick, NJ: Rutgers U. Press, 1990), 70-88; Floris Barnett Cash, African-American Women and Social Action: The Clubwomen and Volunteerism from Jim Crow to the New Deal, 1896-1936 (Westport, CT: Greenwood Press, 2001).
} 
their work outside the home in a socially acceptable manner. While women became involved with almost every aspect of the Progressive movement, municipal housekeeping was one of the easiest ways for them to do so. Municipal housekeeping encompassed the "feminine" work women already did within their own homes, and therefore the public supported the extension of women's work into the larger home of the city. ${ }^{5}$

Women's interest in municipal housekeeping and the public's reaction to it is discussed further in Chapter Two, which begins with a discussion of the nineteenthcentury concept of separate spheres and its effect on the creation of women's clubs and other organizations that brought white, middle-class women out of their homes and into settings for discussion with other women. The chapter examines the history of women's clubs and nineteenth-century women's activism, with the purpose of determining these early organizations’ impact on early twentieth-century women’s clubs. Framed within the context of the burgeoning Progressive movement in the late nineteenth century, Chapter Two discusses the evolution of white, middle-class women’s organizations from benevolence societies and culture clubs to organizations centered on social reform. In addition, Chapter Two also examines women's participation in nearly all aspects of the Progressive movement, including municipal housekeeping, and seeks to determine why social reform work appealed to them. The chapter ends with a discussion of historical literature and examples of how the work of the Progressive Era continued beyond 1917.

\footnotetext{
${ }^{5}$ For more information about the national municipal housekeeping movement, see: Blair, The Clubwoman as Feminist; Wortman, "Domesticating the Nineteenth-Century American City"; Nancy A. Hewitt, "Politicizing Domesticity: Anglo, Black, and Latin Women in Tampa's Progressive Movements" in Gender, Class, Race, and Reform in the Progressive Era, 24-41; Eileen Boris, "Reconstructing the 'Family': Women, Progressive Reform, and the Problem of Social Control” in Gender, Class, Race, and Reform in the Progressive Era, 73-86; and Flanagan, "Gender and Urban Reform."
} 
Chapter Three gives background information on the foundation and history of the Louisville Women's City Club and on Louise Morel's life, family experience, and occupations. It examines how Morel used the City Club to conduct her social surveys, initiate reform projects, and spread her ideas to the people of the city and the state. Perhaps one of the most remarkable aspects of Morel was her sense of her place in history. She kept diligent records of her work including correspondence, survey tables and maps, drafts of speeches and articles, and scrapbooks full of newspaper clippings. Some letters and newspaper clippings have brief notes Morel scribbled on them noting incorrect facts or occasions when the author did not mention her name in association with one of her ideas. The care she put into keeping records extended to the work she did. Her projects and surveys were well-organized and researched, and then presented to the public in a way they could understand.

The following chapters show how Louise Morel and the Louisville Women's City Club kept the ideals of the Progressive Era alive in Louisville from 1917 through the 1930s. Chapter Four discusses Morel’s earliest projects: the 1918 Garbage Disposal and Collections Survey, the 1920 Sanitary Survey, and her work to improve sewer capacity. These were projects common to municipal housekeepers and other city reformers during the Progressive Era. Chapter Five concentrates on Morel's interest in public health. This interest led to organizing the Health Exposition in 1922, conducting a housing survey to determine how best to prevent tuberculosis in 1924, and working to improve and expand two local tuberculosis hospitals. Chapter Six examines Morel's concern for clean and safe housing and public buildings. She chaired the Better Homes in America exhibition for eleven years and conducted two surveys with the City Club: the Housing Survey in 
1934 and the Cleanliness Survey from 1929 through 1931. The purpose of these three chapters is to provide a closer look at social reform after the supposed end of the Progressive movement. Through their surveys and projects in Louisville, Morel and the City Club exuded progressive ideals of hygiene, "improvement” of the poor, and concern for the health and safety of individuals living in the city.

Louise Morel did not become active in municipal housekeeping until 1917, when what traditionally has been classified as the Progressive Era was coming to an end. Morel did the majority of her work during the 1920s and 1930s—well after the Progressive Era and, in the 1920s, a time not often associated with active reform movements. Although Morel and the City Club were at their reforming height in the decades after the Progressive Era and the introduction of municipal housekeeping, their work was based upon and inspired by the reform ideals of that earlier period. Morel carried Progressive Era-style municipal housekeeping through the next two decades in Louisville. Through their surveys, campaigns, lectures, and conventions, Louise Morel and the women of the Louisville Women's City Club were local examples of the national municipal housekeeping movement as it existed after 1917. 


\section{CHAPTER TWO}

\section{THE NATIONAL REFORM MOVEMENT AND WOMEN'S CLUBS}

Louise Morel was only one of many women who were active in social reform during the 1920s and 1930s. Women’s reform work during the earlier Progressive Era, including the municipal housekeeping movement, settlement houses, and other, more well-known female reformers, all influenced Morel's work in the decades after the Progressive Era. The women of the Progressive movement emphasized active social reform over charitable benevolence, which had been the norm in previous decades. Although the Progressive Era introduced new ways for women to work with the poor and immigrants in America's cities, it still drew upon the philanthropic tradition of the earlier nineteenth century.

A discussion of women's interests in active service work outside the home must include a brief analysis of the concept of separate spheres and the "Cult of True Womanhood.” ${ }^{1}$ The gender ideology for white women, which had been in existence since at least the 1830s, became known as "separate spheres" or the "Cult of True

\footnotetext{
${ }^{1}$ For more on the ideology of separate spheres and the "True Woman" see Rosalind Rosenberg, Divided Lives: American Women in the Twentieth Century (New York: Hill and Wang, 1992) and Barbara Welter, “The Cult of True Womanhood, 1820-1860,” American Quarterly 18 (Summer 1966): 151-174. For a discussion on how perceptions of the idea of separate spheres have changed see Sheila Rothman, Woman's Proper Place: A History of Changing Ideals and Practices, 1870 to the Present (New York: Basic Books, Inc., Publishers, 1978). A good historiography on the separate spheres ideology can be found in Linda K. Kerber, “Separate Spheres, Female Worlds, Woman's Place: The Rhetoric of Women’s History,” The Journal of American History 75 (June 1988): 9-39. For an analysis of how female reformers unknowingly perpetuated the concept of separate spheres during the Progressive Era, see Jill Conway, "Women Reformers and American Culture, 1870-1930,” Journal of Social History 5 (1971-1972): 164-177.
} 
Womanhood.”2 This ideology dictated that the woman’s place, or sphere, was in the home. In her private sphere, woman had complete power. Her nature appointed her to care for and educate the children and to manage the home. Many people in the nineteenth century believed that within her private sphere, the woman was elevated. It was her job to bring her family (especially her husband) and her friends up to her level of morality. $^{3}$ The concept of separate spheres applied only to white women, and most often, to those in the middle and upper classes.

\section{Benevolence Societies and Culture Clubs}

Reflecting the "Cult of True Womanhood,” many people, including some women, were critical of the first women's clubs founded in the mid-1800s because the clubs required women to leave the private sphere of the home. ${ }^{4}$ Although, at this same time, some women were venturing out of the home into teaching and millwork, and attending colleges and universities, women who asked for a wider sphere of interests were usually met with resistance. ${ }^{5}$ While clubwomen insisted they could manage both club activities and homemaking, many people believed that joining a women's club would lead to that woman ignoring her household duties. ${ }^{6}$ These individuals believed that if women were expending all of their energy in public and through intellectual means they would not be able to fulfill their expected feminine roles, such as having and caring for children. A woman was encouraged to "not look away from her own little family circle for the means

\footnotetext{
2 Theodora Penny Martin, The Sound of Our Own Voices: Women's Study Clubs 1860-1910 (Boston: Beacon Press, 1987), 118-119.

${ }^{3}$ Ibid., 24.

${ }^{4}$ Ibid., 124.

${ }^{5}$ Ibid., 118; Welter, 152.

${ }^{6}$ Martin, 118-119.
} 
of producing moral and social reforms, but [to] begin at home.”7 Despite criticism, increasing numbers of women in the mid-nineteenth century joined women's clubs.

The most common way for women to become involved in philanthropic work was through joining a benevolence society or other similar organization. Women's voluntary organizations have existed since the early days of United States history, when many of these early organizations were founded as auxiliaries to men's benevolence societies. Their purpose was to achieve a "moral transformation of American society.”8 Women founded these societies and organizations on the belief that they, as women, were morally superior to men and thus more able to provide charity and relief where it was needed. This idea originated from the concept of “True Womanhood.” This ideology dictated that men perpetrated societal evils, such as poverty, hunger, and disease through their work; women, as caretakers of the home and family, were especially equipped to ameliorate these problems through an infusion of their morality. ${ }^{9}$

Although the early benevolence societies wielded some amount of power in community decisions, their members downplayed this fact, preferring to keep to the concept of the passive, moral woman. When they were criticized for ignoring their homes and families to do charitable work, women insisted they were only doing their duty as “True Women.” Their work within benevolence societies was extending their moral reach outside the home to the city at large. It was a logical extension of their responsibilities as women at home. ${ }^{10}$ The home-to-city argument became a common defense, first among benevolent women, and later among reform-oriented women. It

\footnotetext{
${ }^{7}$ Welter, 163.

${ }^{8}$ Lori Ginzberg, Women and the Work of Benevolence: Morality, Politics, and Class in the NineteenthCentury United States (New Haven: Yale U. Press, 1990), 99.

${ }^{9}$ Ibid., 11-12, 16.

${ }^{10}$ Ibid., 16, 53, 65-66.
} 
served as a way for these women to work outside their homes while placating both critics and their own doubts.

Existing concurrently with benevolence organizations during the nineteenth century were women’s culture, or study, clubs. Culture clubs’ primary purpose was selfeducation, but being able to socialize with other women was a welcome bonus. Some culture clubs studied everything from the literary classics to natural science, while others focused on topics within one area of study such as art, literature, music, or current events. The clubs usually consisted of middle-class white women of all ages, including college graduates who wanted intellectual stimulation and women of varying religions and interests. The culture clubs brought together women who may otherwise never have met, as well as women who were already acquainted. Joining culture clubs resulted in the breakdown of many cliques and other distinctions within the middle class, as these new clubwomen had been accustomed to associating only with those "determined by kinship and by religious and political sympathies, associations 'with our own kind.’”11

Within the confines of the culture club setting, women were able to gain a sense of individuality. ${ }^{12}$ Most clubs met in members' homes, where women felt most comfortable. This allowed culture clubs to be viewed as an extension of friendship; women had always socialized together in their homes. ${ }^{13}$ Throughout their lives, women had been told "not to speak up in public, to avoid politics, and to defer higher education to their brothers.” Therefore, many women were hesitant to speak their opinions on various subjects to a group. Within the culture club however, clubwomen

\footnotetext{
${ }^{11}$ Karen Blair, The Clubwoman as Feminist: True Womanhood Redefined (New York: Holmes and Meier Publishers, 1980), 9-10; Martin, 126-7.

12 Martin, 132.

${ }^{13}$ Ibid., 29-30.
} 
"expressed...humble opinions freely over the tea-cups," according to Celia Burleigh, a member of Jennie C. Croly's Sorosis Club in New York. Club members learned cooperation and how to yield to the will of the majority, in contrast to the individual woman at home who made all of the household decisions herself. Clubwomen also learned self-confidence, leadership, money-raising (mostly for clubhouses), and public speaking, traits that were considered to be masculine at the time. ${ }^{14}$

Women's culture clubs and benevolence societies have been legitimate subjects of historical research for only about twenty-five years. Historian Anne Firor Scott has written extensively about early women’s voluntary organizations, groups she has termed "invisible" because of the previous lack of historical interest in them. ${ }^{15}$ Since Scott wrote about women's organizations in the 1980s, other historians have begun studying and researching women's voluntary organizations and culture clubs. Scott’s works, however, remain useful, as she was the first to uncover the rich history of women's organizations. Karen Blair's The Clubwoman as Feminist: True Womanhood Redefined, published in 1980, remains the most comprehensive work on the development of women's clubs and their struggle to reconcile their public interests with their desire to remain "True Women.” Historian Theodora Penny Martin wrote a detailed book on culture clubs' formation, their activities, and the changes the clubs underwent from the mid-1860s through the first decade of the twentieth century. Martin also explored the changes the clubwomen themselves experienced upon joining a culture club, and examined reactions from communities towards culture clubs. Another work, Women and the Work of

\footnotetext{
${ }^{14}$ Ibid., 126, 131-2; Blair, 8.

${ }^{15}$ Anne Firor Scott's works on early women's voluntary organizations include "As Easily as They Breathe..." and "Women's Voluntary Associations in the Forming of American Society" in Making the Invisible Woman Visible, ed. by Anne Firor Scott (Urbana, IL: U. of Illinois Press, 1984).
} 
Benevolence: Morality, Politics, and Class in the Nineteenth-Century United States, written by historian Lori Ginzberg, traces the development of and changes in the methods used by benevolent organizations in achieving their goals. ${ }^{16}$

\section{Anti-Slavery, Women's Rights, and Temperance Organizations}

Several other voluntary organizations that cannot be considered benevolent societies or culture clubs existed during the nineteenth century. The anti-slavery movement and the women's rights movement resulted in numerous organizations. The anti-slavery movement is most often dated to the 1830s when William Lloyd Garrison founded the American Anti-Slavery Society (AASS). Women’s participation, represented most often by the activism of Sarah and Angelina Grimke, can also be dated to the 1830 s. ${ }^{17}$ Women joined the AASS but also founded anti-slavery societies exclusively for women, most notably the Philadelphia Female Anti-Slavery Society and the Boston Female Anti-Slavery Society. Women active in anti-slavery groups differed from those active in benevolent societies or culture clubs. Women in anti-slavery organizations pioneered the public activism that would not be adopted by most women's voluntary organizations until the late nineteenth century when social reform became a primary concern. The Grimke sisters and other anti-slavery women promoted their cause through public speaking, petitioning, mailing pamphlets, writing articles and letters, and meeting in conventions. These actions set them apart from the work of women

\footnotetext{
${ }^{16}$ See Martin, The Sound of Our Own Voices; Blair, The Clubwoman as Feminist; and Ginzberg, Women and the Work of Benevolence.

${ }^{17}$ Kathryn Kish Sklar, Women's Rights Emerges Within the Anti-Slavery Movement, 1830-1870: A Brief History with Documents (Boston and New York: Bedford/St. Martin’s, 2000), ix.
} 
benevolent societies and culture clubs; anti-slavery women took steps into the world of politics forty years before most other reform-oriented women. ${ }^{18}$

In addition to being the foremost female anti-slavery activists, the Grimkes were also some of the first promoters of the women's rights movement. In their writings and speeches, the Grimkes asserted that women could do the same things as men (such as public speaking) and therefore deserved the same rights as men. Drawing parallels between the limited rights of women and slaves, the Grimkes pointed out the main issue that would divide the anti-slavery movement in the years leading up to the Civil War. By the 1840s, women's rights became an issue separate from the anti-slavery movement. Women such as Lucretia Mott, Elizabeth Cady Stanton, Lucy Stone, and Susan B. Anthony propelled the women's rights movement into the public eye in the midnineteenth century. ${ }^{19}$

Both anti-slavery and the women’s rights movements had considerable influence, especially in the area of women's increasing involvement in the public sphere, on the reform-oriented voluntary organizations of the 1890s and the early twentieth century. The primary difference between those early movements and the later reform movement is the appeal they held toward everyday, middle class women. Perhaps because the antislavery movement and the women's rights movement used methods so new to women, they did not have broad appeal to American women. In contrast, after these outspoken methods became more acceptable for women, the reform organizations of the Progressive Era drew incredible numbers of women to membership in the General Federation of Women's Clubs, the Women’s Christian Temperance Union, and other similar groups.

\footnotetext{
${ }^{18}$ Sklar, 1, 8-9, 25-26; Susan Zaeske, Signatures of Citizenship: Petitioning, Antislavery, and Women's Political Identity (Chapel Hill, NC: U. of North Carolina Press, 2003), 1.

${ }^{19}$ Sklar, 28, 35-36, 49.
} 
Another example of nineteenth-century women's activism is the Women's Christian Temperance Union (WCTU) ${ }^{20}$ Throughout the nineteenth century, temperance movements were successful in gathering women outside their homes to combat the sale and consumption of alcohol. Various temperance-oriented organizations proliferated in the mid-nineteenth century. These groups formed the WCTU as a national organization in 1874. During the first few years of the WCTU, the organization was mostly benevolent in its actions. It made education, religious conversion, and the promotion of abstaining from alcohol its primary goals. Like women's culture clubs and benevolent societies, the WCTU drew most of its members from the middle class. Contact with poorer classes was "maternalistic"; contact with the poorer classes on an equal level was nonexistent. ${ }^{21}$ As with culture clubs and benevolence societies, the focus of the WCTU changed in the late nineteenth century.

\section{From Benevolence to Reform}

Gradually, from the years after the Civil War through the 1890s, the reform impulse overtook the benevolence ideal. Likewise, the WCTU, women's culture clubs and some benevolence societies began to include more reform-oriented activities in their agendas. For the WCTU, these changes began with the election of Frances Willard as president in $1879 .{ }^{22}$ Willard's "Do Everything" policy expanded the work of the WCTU

\footnotetext{
${ }^{20}$ For more information on the WCTU and the temperance movement in general see Jack S. Blocker, Jr., American Temperance Movements: Cycles of Reform (Boston: Twayne Publishers, 1989) and Ruth Bordin, Woman and Temperance: The Quest for Power and Liberty (Philadelphia: Temple U. Press, 1981). For an analysis on the role of religion in the temperance movement see Barbara Leslie Epstein, The Politics of Domesticity: Women, Evangelism, and Temperance in Nineteenth-Century America (Middletown, CT: Wesleyan U. Press, 1981).

${ }^{21}$ Blocker, 79-81.

${ }^{22}$ Willard described her vision and the work of the WCTU in Woman and Temperance: Or, The Work and Workers of the Woman's Christian Temperance Union (Hartford: Park Publishing Co., 1883). See also Ruth Bordin's biography of Frances Willard, Frances Willard: A Biography (Chapel Hill and London: U. of North Carolina Press, 1986).
} 
into other areas of active reform. By the 1880s, the WCTU consisted of several different departments dedicated to various areas of reform (including temperance) similar to those of the General Federation of Women's Clubs (GFWC). ${ }^{23}$ When the GFWC was founded in 1890, its constitution stated that member clubs’ work should be cultural, studying music, art, or science. By the next year, Jennie June Croly, the founder of the notable New York Sorosis club, proposed that the GFWC include social service as a legitimate club purpose. By the mid-1890s, the majority of individual women's clubs were focusing on community betterment activities, although they often kept study, art, and music departments. Heeding this change in club goals, the GFWC added reform work to its list of club work and began to encourage clubs to focus on it over cultural pursuits. ${ }^{24}$ This growing interest and focus on community service and reform coincided with the beginning of the Progressive movement that swept the United States in the late nineteenth and early twentieth centuries.

Women’s clubs’ shift from benevolent and study work to reform has received some attention from historians. In The Sound of Our Own Voices: Women's Study Clubs, 1860-1910, Theodora Penny Martin examined how some culture clubs transformed into service clubs while others kept study as their primary focus. ${ }^{25}$ Historian Lori Ginzberg examined the shift from an emphasis on benevolence to the promotion of active reform within women's clubs and other female voluntary organizations. ${ }^{26}$ Karen Blair's The Clubwoman as Feminist: True Womanhood Redefined, 1868-1914 provided a detailed look at various clubs and other female organizations affected by the shift into reform

\footnotetext{
${ }^{23}$ Blocker, 84-85.

${ }^{24}$ Barbara K. Campbell, The "Liberated" Woman of 1914: Prominent Women in the Progressive Era (N.c.: UMI Research Press, 1979), 151-152.

${ }^{25}$ See Martin, The Sound of Our Own Voices.

${ }^{26}$ See Ginzberg, Women and the Work of Benevolence.
} 
work. ${ }^{27}$ Blair traced the beginnings of reform work to the founding of the first two reform-oriented women's clubs in 1868-Sorosis in New York City and the New England Woman’s Club in Boston. ${ }^{28}$

The Progressive movement also saw a decline in passive benevolent societies, resulting from an increasing interest in more active, scientific reform work. Lori Ginzberg dated the beginnings of a shift from benevolent work to active reform to the 1860s, noting specifically the creation of the Sanitary Commission during the Civil War. The women who became nurses in the Sanitary Commission, especially the younger women, saw their roles as unsentimental and scientific. They had no need for the older “virtuous woman” style of benevolence. ${ }^{29}$ The orderly, businesslike Sanitary Commission was a predecessor to the women's reform movement that took hold in the 1890s.

As the social reform movement grew, it became increasingly geared toward women. Although the Progressive movement involved both men and women, women were the ones who carried out the everyday ideals of the movement. ${ }^{30}$ At first, the idea of women leaving their homes to do any sort of work that was not specifically geared toward the home was scandalous. Thus, the first women who ventured into the world of reform work were women with college degrees, women who had already flouted the

\footnotetext{
${ }^{27}$ See Blair, The Clubwoman as Feminist.

${ }^{28}$ Ibid., 5.

${ }^{29}$ Ginzberg, 147-149.

${ }^{30}$ Historian Marlene Stein Wortman denoted two types of Progressivism: domestic and professional. Domestic Progressives tended to be women who viewed the city as a large home and therefore worked on "moral" and social projects that benefited the community as a whole. Professional Progressives were usually men who saw the city primarily as a business and cultural center. Their work concentrated on aspects that would make the city more desirable to businesses. For more information see Marlene Stein Wortman, "Domesticating the Nineteenth-Century American City," Prospects: An Annual of American Cultural Studies, 3 (1977): 531-572. These two different ways of thinking led to conflicts when trying to decide what was best for the city. Historian Maureen Flanagan documents these types of conflicts between Chicago men and women in "Gender and Urban Reform: The City Club and the Women's City Club of Chicago in the Progressive Era,” The American Historical Review 95 (Oct. 1990): 1032-1050.
} 
norm. ${ }^{31}$ Usually, these college-educated women first worked to improve public schools, and then continued to work as "municipal housekeepers," improving the living conditions in cities. ${ }^{32}$ Historian Karen Blair called their work “domestic feminism,” which she defined as women using their feminine characteristics to extend their work outside the home. ${ }^{33}$ The most natural way for women's clubs and organizations to begin their reform work was through bettering the lives of women and children, a focus that remained the center of women's reform work even through the early 1940s. Reformers soon found the best way to make effective changes in the lives of women and children was through state and national legislation. Throughout the Progressive Era, women campaigned for new laws that would necessitate reforms in various aspects of society. Large organizations, such as the General Federation of Women's Clubs and their state federations, organized immense legislative efforts that often resulted in success.

In 1889, only three percent of social workers were female. By 1910, this number had increased to such an extent that women made up the majority of social workers. ${ }^{34}$ By the 1910s, women's involvement in social work had come to be accepted. It was, after all, a logical extension of the work women did at home, as these women were simply "housekeeping" for the community and attempting to bring the poor in line with their own morals. ${ }^{35}$ By the late 1910 s, social work, especially non-professional social work, had become increasingly relegated to women and women came to dominate the reform movement.

\footnotetext{
${ }^{31}$ Rosenberg, 25.

${ }^{32}$ Martin, 4.

${ }^{33}$ Blair, 4.

${ }^{34}$ Rosenberg, 29.

${ }^{35}$ Ibid., 30.
} 
Individual clubs began to turn to reform at about the same time the General Federation of Women's Clubs and the various state federations formed in the 1890s. One early history of the GFWC is Mary I. Wood's The History of the General Federation of Women's Clubs.... ${ }^{36}$ This work provided the minutes for the GFWC's biannual meetings through 1912. Another, more detailed history, is Mildred White Wells' Unity in Diversity: The History of the General Federation of Women's Clubs, published in $1953 .{ }^{37}$ Neither work gave much analysis; they focused on GFWC meetings, organization, and membership. Wells' book also included brief assessments of work completed by the GFWC and state federations. Many of the state federations have since published their own histories, Kentucky included. ${ }^{38}$ While these histories give one an idea of the functions of women's clubs and their organization, they are not entirely objective; many of the state federation histories are published by and for the state federations.

As discussed earlier, the Progressive Era ushered in a change in the focus of women's clubs. Beginning in the 1890s, women's clubs sought to better their community and their country. The ways in which they attempted to initiate these changes were varied. Historian Karen Blair examined the ways in which women's clubs used the separate spheres stereotype to their own advantage in their quest to become involved in reform activities. ${ }^{39}$ The clubwomen maintained they were especially qualified to involve themselves in improving education, cleaning up the city, preventing illness, and investigating problems related to housing, health, and women's and children's affairs

\footnotetext{
${ }^{36}$ Mary I. Wood, The History of the General Federation of Women's Clubs for the First Twenty-Two Years of its Organization (New York: The History Department, GFWC, 1912).

${ }^{37}$ Mildred White Wells, Unity in Diversity: The History of the General Federation of Women's Clubs (Washington, DC: General Federation of Women's Clubs, 1953).

${ }^{38}$ For the Kentucky Federation of Women's Clubs' history see Janice Theriot, Tradition of Service: A History of the Kentucky Federation of Women's Clubs (Louisville, KY: Kentucky Federation of Women's Clubs, 1994).

${ }^{39}$ See Blair, The Clubwoman as Feminist.
} 
since, as women, they were responsible for doing all of these things within their own homes. ${ }^{40}$ Historian Suzanne Lebsock took this idea in another direction. ${ }^{41}$ Lebsock saw women’s membership in voluntary organizations as a way in which women could participate in politics. Although they could not vote, and many did not affiliate themselves with political parties, clubwomen exerted political influence in other, more socially acceptable manners such as using their status to persuade legislators and other government leaders to their points of view.

The majority of clubs studied by historians have been middle-class white women's clubs. Excluded by most white clubs, African-American women founded their own clubs. They too focused on initiating reforms, some the same as the white clubs, but others uniquely important to black women. ${ }^{42}$ Believing that a "community could rise no higher than its womanhood,” black clubwomen also concentrated their reform work on

\footnotetext{
${ }^{40}$ For a critical analysis on the reasoning behind female reformers' desire to shape poor homes and families to be more middle class see: Eileen Boris, "Reconstructing the 'Family': Women, Progressive Reform, and the Problem of Social Control" in Gender, Class, Race, and Reform in the Progressive Era, ed. by Noralee Frankel and Nancy S. Dye (Lexington, KY: The U. Press of Kentucky, 1991), 73-86; and Ginzberg, Women and the Work of Benevolence.

${ }^{41}$ See Suzanne Lebsock, “Across the Great Divide: Women and Politics, 1890-1920" in Women, Politics, and Change, ed. by Louise Tilly and Patricia Gurin (New York: Russell Sage Foundation, 1990), 35-62.

${ }^{42}$ For more on the founding of black women's clubs, their federation, and the reforms they worked for see: Floris Barnett Cash, African-American Women and Social Action: The Clubwomen and Volunteerism from Jim Crow to the New Deal, 1896-1936 (Westport, CT: Greenwood Press, 2001); Linda Gordon, "Black and White Visions of Welfare: Women's Welfare Activism, 1890-1945,” The Journal of American History 78 (Sept. 1991): 559-590; Nancy A. Hewitt, "Politicizing Domesticity: Anglo, Black, and Latin Women in Tampa's Progressive Movements" in Gender, Class, Race, and Reform in the Progressive Era, 24-41; Darlene Clark Hine, "We Specialize in the Wholly Impossible: The Philanthropic Work of Black Women" in Lady Bountiful Revisited: Women, Philanthropy, and Power, ed. by Kathleen D. McCarthy (New Brunswick, NJ: Rutgers U. Press, 1990), 70-88; Beverly W. Jones, "Mary Church Terrell and the National Association of Colored Women, 1896-1901," The Journal of Negro History 67 (Spring 1982): 20-33; Anne Meis Knupfer, Toward a Tenderer Humanity and a Nobler Womanhood: African-American Women's Clubs in Turn-of-the-Century Chicago (New York: New York U. Press, 1996); Priscilla Munrolo, The Common Ground of Womanhood: Class, Gender, and Working Girls' Clubs, 1884-1928 (Urbana, IL: U. of Illinois Press, 1997); Anne Firor Scott, "Most Invisible of All: Black Women’s Voluntary Associations," The Journal of Southern History 56 (Feb. 1990): 3-22; Stephanie J. Shaw, "Black Club Women and the Creation of the National Association of Colored Women,” The Journal of Women's History 3 (Fall 1991): 10-25; and Deborah Gray White, "The Cost of Club Work, The Price of Black Feminism” in Visible Women: New Essays on American Activism, ed. by Nancy Hewitt and Suzanne Lebsock (Urbana, IL: U. of Illinois Press, 1993), 247-269.
} 
women and children. African-American reform-oriented clubs, like white women's clubs, sought to aid the poor, clean up neighborhoods, combat diseases, and improve the lives and education of children. However, black clubwomen also worked on antilynching campaigns; helped single, working mothers find decent jobs; founded day cares for the children of working mothers; established safe homes where young, single, working women and girls could live; and fought for respectability for themselves and all black women. Many of these clubs joined the National Association of Colored Women (NACW), founded in $1896 .{ }^{43}$ The women of the NACW saw themselves as leading the African-American race in the fight to gain equality and respect from whites.

\section{Women and Progressive Ideals}

Clubs were not the only way for women to become involved in the reform

movement. Living and working in one of the many settlement houses founded in United States cities in the late nineteenth century offered one of the most well-known ways in which women could become involved in service. Allen Davis’ work, Spearheads for Reform: The Social Settlements and the Progressive Movement, 1890-1914, provided one of the most comprehensive looks at the history of the settlement movement in the United States. ${ }^{44}$ Davis traced the origins of settlement houses to their beginnings in England,

\footnotetext{
${ }^{43}$ White, 247-248.

${ }^{44}$ Allen F. Davis, Spearheads for Reform: The Social Settlements and the Progressive Movement, 18901914 (New York: Oxford U. Press, 1967). See also Mina Carson, Settlement Folk: Social Thought and the American Settlement Movement, 1885-1930 (Chicago: U. of Chicago Press, 1990). Jane Addams, perhaps the most well-known settlement advocate, wrote about her experiences living and working at the Hull House settlement in Chicago in Jane Addams, Twenty Years at Hull House (New York: The Macmillan Co., 1911) and Jane Addams, The Second Twenty Years at Hull House (New York: The Macmillan Co., 1930). Lillian Wald also wrote about her time at the Henry Street Settlement in New York City in: Lillian D. Wald, The House on Henry Street (New York: H. Holt and Co., 1915). Two other autobiographical settlement house works are: Mary Kingsbury Simkhovitch, Neighborhood: My Story of Greenwich House (New York: Norton, 1938) and Graham Taylor, Chicago Commons Through Forty Years (Chicago: Chicago Commons Association, 1936). For information on African-American settlements, which were founded in several cities where blacks were excluded from the mainstream settlements, see Elisabeth Lasch-Quinn, Black Neighbors: Race and the Limits of Reform in the American Settlement House
} 
from where their ideals quickly spread to the United States. College students and ministers often founded and staffed the settlement houses that proliferated throughout the cities of the Northeast and the Midwest United States. ${ }^{45}$ Both men and women became involved in settlement houses, but women prospered especially through their involvement with settlements. Many of the well-known female social reformers of the late nineteenth and early twentieth centuries, including Jane Addams, Lillian Wald, Edith and Grace Abbott, Julia Lathrop, Mary McDowell, and Florence Kelley, among others, spent time living and working in settlement houses.

Perhaps as a result of women's involvement settlement houses, they did their most influential work among the women and children of the poor. Settlements organized day cares and kindergarten programs, cultural programs, and practical classes for women. They also provided a place for socialization, offered vocational training and career counseling, and even employed nurses to tend to sick children. ${ }^{46}$ Settlement workers tried to improve the surrounding neighborhood through bettering public schools and building playgrounds and parks. ${ }^{47}$ Some settlements worked to eliminate corruption from local elected offices through finding and campaigning for new candidates; others became involved in the labor movement and allowed unions to meet at the settlement houses. ${ }^{48}$

Although settlements are one of the most recognized ways in which women were involved in reform, there were other opportunities open to women. The Children's

\footnotetext{
Movement, 1890-1945 (Chapel Hill, NC: The U. of North Carolina Press, 1993). For histories on individual settlements see: Ruth Hutchinson Crocker, Social Work and Social Order: The Settlement Movement in Two Industrial Cities, 1889-1930 (Urbana, IL: U. of Illinois Press, 1992), Howard Jacob Karger, "Phyllis Wheatley House: A History of the Minneapolis Black Settlement House, 1924-1940," Phylon 47 (1986): 79-90, and Howard Jacob Karger, The Sentinels of Order: A Study of Social Control and the Minneapolis Settlement House Movement, 1915-1950 (Lanham, MD: U. Press of America, Inc., 1987).

${ }^{45}$ Davis, 18.

${ }^{46}$ Ibid., 45-46, 50-51, 55.

${ }^{47}$ Ibid., 55, 63-64, 81.

${ }^{48}$ Ibid., 103-122, 148-169.
} 
Bureau was one option. A creation of the 1920s, the Children's Bureau opened up a part of government to women. Women were in charge of and staffed almost every level of the Bureau's work. Molly Ladd-Taylor studied the Bureau and the tactics it used to aid women across the country in raising healthy children. ${ }^{49}$ Ladd-Taylor noted the two functions of the Bureau: to increase the number of healthy babies and to regulate child labor. ${ }^{50}$ These two goals drew very different responses from the women the Bureau sought to serve. Women of all races and classes embraced the Bureau's tips on raising healthy children. However, when the Bureau began to work against child labor, many of the women who had come to trust the Bureau turned against it. These women were often poor and lived in rural areas; their families survived on the work done by their children. ${ }^{51}$ Ladd-Taylor's article examined this contradiction in the work of the Children's Bureau.

\section{Municipal Housekeeping}

Like the Children's Bureau and settlement houses, the Progressive Era and the years following 1917 offered several other opportunities for women to work for issues in which they believed. These issues included everything from the creation of a welfare system to anti-lynching campaigns. ${ }^{52}$ Most of these issues involved, in some way, the concept of municipal housekeeping. Municipal housekeeping, meaning the literal cleaning up of a city, appealed to many reform-minded women. It was one of the first ways women were able to get involved in the Progressive movement, and it was one of

\footnotetext{
${ }^{49}$ See Molly Ladd-Taylor, "Hull House Goes to Washington: Women and the Children's Bureau" in Gender, Class, Race, and Reform in the Progressive Era, 110-126.

${ }^{50}$ Ibid., 110.

${ }^{51}$ Ibid., 119, 123

${ }^{52}$ On the creation of welfare see: Linda Gordon, Pitied but Not Entitled: Single Mothers and the History of Welfare, 1890-1935 (New York: Free Press, 1994). On the fight against prostitution see: Ruth Rosen, The Lost Sisterhood: Prostitution in America, 1900-1918 (Baltimore: The Johns Hopkins U. Press, 1982). On anti-lynching campaigns see: Rosalyn Terborg-Penn, “African-American Women's Networks in the AntiLynching Crusade" in Gender, Class, Race, and Reform in the Progressive Era, 148-161.
} 
the longest lasting. Women were involved in municipal housekeeping at the beginning of the Progressive Era and are still involved today through various organizations. Marlene Stein Wortman's article, “Domesticating the Nineteenth-Century City,” provided a concise analysis of municipal housekeeping and sought to explain why and how women were drawn to it. ${ }^{53}$ Wortman concentrated on showing how reformers, using the separate spheres ideology, emphasized municipal housekeeping as the perfect way for women to enter the reform movement. An article by Maureen Flanagan gave an excellent look at an individual club's work, most of which involved what would be classified as municipal housekeeping. ${ }^{54}$ Flanagan compared the ways in which the Chicago Women's City Club suggested reforming city services to the ways in which their male counterpart, the Chicago City Club, did. For example, both clubs researched how the city could provide better garbage collection and elimination and came to different conclusions. The male City Club believed it was best to keep garbage collection by private companies because private collection was more cost-efficient. In addition, the City Club found that garbage reduction, packing the garbage so that more could fit into a space, was a better option than incineration because reduction would give a greater profit to private companies than would incineration. The Women’s City Club, however, favored city control over garbage collection because the benefits would go to the city, and preferred incineration of garbage because it was more sanitary than reduction. While the male City Club was more concerned with the success of private business and making a profit, the Women's City Club had a greater interest in the health and cleanliness of the city and its residents. ${ }^{55}$

\footnotetext{
${ }^{53}$ Wortman, "Domesticating the Nineteenth-Century City."

${ }^{54}$ Flanagan, "Gender and Urban Reform."

${ }^{55}$ Ibid., 1037-1039.
} 
As its name implied, the central idea of municipal housekeeping was viewing the city as one large home. Therefore, municipal housekeepers were interested in keeping the city's streets and alleys free of litter, its homes well-ventilated and roomy, its people safe from disease and crime, its children educated and able to play, and its public buildings clean and safe. Public health was also a primary concern of municipal housekeepers. ${ }^{56}$ Women believed it was their personal duty to make the city as safe and comfortable as their individual homes; in doing so they would become even better women. ${ }^{57}$ Municipal housekeepers also used a moral argument to support their work, stating that it was their responsibility to spread the morality within their homes to the city at large, and especially to the poor and immigrants. ${ }^{58}$ Municipal housekeepers believed that filth and unsavory housing conditions drew down the morals of the poor, and therefore, through cleaning up the city, the morals of its inhabitants would improve. ${ }^{59}$

Reformers employed several methods to conduct the work of municipal housekeeping. One of the most often used was the social survey. ${ }^{60}$ Historian Michael Gordon attributed the rise of social surveys in the late nineteenth and early twentieth centuries in the United States to the increasing working population. The increasing population strained charitable services and led to reformers’ and social workers’ desire to enumerate the poorer classes and develop policies both to aid and contain them. ${ }^{61}$ In the United States, the Pittsburgh Survey, begun in 1907, was the first major social survey. Its goal was to find the "societal roots" of problems, such as crime and alcoholism, which

\footnotetext{
${ }^{56}$ For more information about public health in the 1920s and 1930s, see John Duffy, The Sanitarians: A History of American Public Health (Urbana, IL: U. of Illinois Press, 1990), especially Chapter Fourteen.

${ }^{57}$ Blair, 48-49.

${ }^{58}$ Wortman, 535.

${ }^{59}$ Ibid., 553.

${ }^{60}$ For more on the development of social surveys in the United States see Michael Gordon, "The Social Survey Movement and Sociology in the United States,” Social Problems 21 (Fall 1973): 284-298.

${ }^{61}$ Ibid., 285-286.
} 
plagued the poor. ${ }^{62}$ Paul U. Kellogg was in charge of conducting and organizing the survey, but women did most of the actual surveying work. ${ }^{63}$ Future social surveys, including those conducted by Louise Morel, were modeled on the Pittsburgh Survey.

Within the clubs and other voluntary organizations that concentrated on municipal

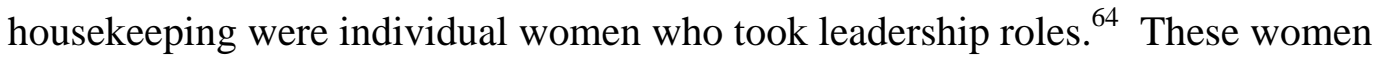
organized their groups’ work and ambitions through directing their service activities. They may have served as club presidents or in other club offices, organized activities such as fund drives, letter-writing campaigns, surveys, and conventions, volunteered to work with children or the poor, given lectures, or persuaded others to become involved in the club’s activities. Some of these women, such as Jane Addams, Lillian Wald, and Ida B. Wells, became nationally known for their reform work. The majority, however, were known only in their own communities as leaders in the reform movement. Louise C. Morel was one of these women. Although she made a name for herself in Louisville during the 1920s and 1930s and was involved in national organizations, Morel was never as well-known as Jane Addams.

${ }^{62}$ Ibid., 291-292.

${ }^{63}$ Ibid.

${ }^{64}$ For more information on individual female reform leaders see: Jane Addams, My Friend, Julia Lathrop (New York: Macmillan, 1935); Addams, Twenty Years at Hull House and The Second Twenty Years at Hull House; Dorothy R. Blumberg, Florence Kelley: The Making of a Social Pioneer (New York: A.M. Kelley, 1966); Sophonisba Preston Breckinridge, Madeline McDowell Breckinridge: A Leader in the New South (Chicago: U. of Chicago Press, 1921); Lela B. Costin, Two Sisters for Social Justice: A Biography of Grace and Edith Abbott (Urbana, IL: U. of Illinois Press, 1983); Louise de Koven Bowen, Growing Up With a City (New York: The Macmillan Co., 1926); Josephine C. Goldmark, Impatient Crusader: Florence Kelley's Life Story (Urbana, IL: U. of Illinois Press, 1953); Caroline Miles Hill, Mary McDowell and Municipal Housekeeping: A Symposium (Chicago: Lithographed by Millar Publishing Co., 1938); Jones, "Mary Church Terrell and the National Association of Colored Women”; Cynthia Neverdon-Morton, AfroAmerican Women of the South and the Advancement of the South and the Advancement of the Race, 18951925 (Knoxville, TN: U. of Tennessee Press, 1989); Jacqueline A. Rouse, Lugenia Burns Hope: Black Southern Reformer (Athens, GA: The U. of Georgia Press, 1989); Patricia A. Schechter, Ida B. WellsBarnett and American Reform, 1880-1930 (Chapel Hill, NC: U. of North Carolina Press, 2001); Barbara Sicherman, "Working it Out: Gender, Profession, and Reform in the Career of Alice Hamilton" in Gender, Class, Race, and Reform in the Progressive Era, 127-147; Terborg-Penn, "African-American Women's Networks in the Anti-Lynching Crusade”; Wald, The House on Henry Street; Howard Eugene Wilson, Mary McDowell, Neighbor (Chicago: U. of Chicago Press, 1928). 


\section{The Progressive Era Extended}

Morel was most active in reform work between 1917 and 1944, a period that began at the end of the Progressive Era and stretched long after it. The years between the end of World War I and the start of the New Deal is not considered a time rich in reform movements. However, the reformers of the 1910s did continue their work through the 1920s, despite encountering more resistance during the latter decade.

Reform work in education, city services, and public health continued into the 1920s and 1930s. Public health remained a vital interest for reformers, especially women reformers, after 1917 . Tuberculosis continued to be a disease that both women and men worked to prevent and to provide those with the disease care and treatment. Germs, in general, became a target to eliminate within the home and public places through dusting, correct packaging of food, and correct disposal of garbage. Historian Nancy Tomes examines public health and how reformers tried to combat disease during the late nineteenth and twentieth centuries. ${ }^{65}$ Tomes notes that although the methods used to combat disease and to educate the public changed and the national drive to fight germs diminished after World War I, reformers remained committed to public health. ${ }^{66}$

Only one work has sufficiently dealt with reform in the 1920s: Clarke Chambers’ Seedtime of Reform: American Social Service and Social Action, 1918-1933. ${ }^{67}$ According to Chambers, reformers at the end of World War I restarted reform work with renewed zeal. They believed the public would agree with them that fixing problems at

\footnotetext{
${ }^{65}$ See Nancy Tomes, The Gospel of Germs: Men, Women, and the Microbe in American Life (Cambridge, MA: Harvard U. Press, 1998).

${ }^{66}$ Tomes, 243-245.

${ }^{67}$ Clarke Chambers, Seedtime of Reform: American Social Service and Social Action, 1918-1933 (Minneapolis: U. of Minnesota Press, 1963).
} 
home was in keeping with the ideals of the democracy they had fought to protect during the war. However, the 1920s brought new obstacles to the reform movement. The Red Scare led many to view reform as anti-American, while an increased number of strikes scared many from supporting reforms that would help labor unions. Increased prices led to a drop in private contributions to reform-oriented organizations. Overall, there was less tolerance for the ideals of social justice that reformers preached. ${ }^{68}$

Despite these obstacles, reformers continued their work through the 1920s, as evidenced by the passage of the Sheppard-Towner Maternity and Infancy Act in 1921, the White House Conferences on Child Health and Protection in the 1920s and 1930s, and the prohibition of liquor in $1920{ }^{69}$ Among these later reformers was Louise C. Morel, Louisville’s most prominent municipal housekeeper.

\footnotetext{
${ }^{68}$ Ibid., 23-25.
}

${ }^{69}$ Ibid., 50, 55-56 


\section{CHAPTER THREE}

\section{LOUISE MOREL AND THE LOUISVILLE WOMEN'S CITY CLUB}

Throughout the years she spent working for social reforms, Louise Morel was an active member and leader of the Louisville Women’s City Club. The City Club, like most women’s clubs in Kentucky, maintained membership in the KFWC. Morel held several offices within the KFWC, most pertaining to public health reforms. Morel's work was welcome within the larger organization, as the KFWC had been promoting reforms since its inception in 1894. As an office holder, Morel relied on KFWC clubwomen to spread her ideas on municipal housekeeping and reform.

The year the KFWC was founded, the GFWC held its Biannual Convention in Louisville, at which time it was definitively noted that "education, no longer of self, but for service” was the goal of most individual women's clubs. ${ }^{1}$ Therefore, from its founding in 1894, the KFWC has been a service-oriented organization. The organization consisted of various service departments including Education, Public Welfare, Social Hygiene, Civics, Industrial and Child Labor, Moral Sanitation, and Food Sanitation. ${ }^{2}$ Through the projects sponsored by these departments, clubwomen could participate in any number of services to the community. As social work was the focus of the KFWC, women from various clubs, including the Louisville Women’s City Club, completed

\footnotetext{
${ }^{1}$ Mary I. Wood, The History of the General Federation of Women's Clubs for the First Twenty-two Years of its Organization (New York: The General Federation of Women’s Clubs, 1912), 86.

2 Janice Theriot, Tradition of Service: A History of the Kentucky Federation of Women's Clubs, 1894-1994 (Louisville, KY: Kentucky Federation of Women’s Clubs, 1994), 82.
} 
innumerable projects and achieved several social reforms. The Louisville Women's City Club was perhaps one of the most active of Kentucky's women's clubs in the area of social reform from the 1910s through the 1940s.

\section{The Louisville Women's City Club}

The Louisville Women's City Club was formed from the Louisville Women's Civic Association which existed only two years, from 1915 through 1917. ${ }^{3}$

Representatives from the city's various women's clubs engaged in social reform comprised the Civic Association’s membership. In February 1917, Civic Association members disbanded the organization and formed the Louisville Women's City Club, a club that stood separate from other women's clubs. The newly-formed City Club sought to continue and broaden the work of the Civic Association. ${ }^{4}$ The City Club quickly made a name for itself in social reform and often was featured in Louisville's newspapers.

Membership in City Club quickly grew and added hundreds of white, middleclass members. By the early 1920s the club had created a Highlands branch in order to accommodate its increasing membership. Like its parent organization, the Highlands division of the City Club was formed from a women’s civic association, the Highland Civic League. ${ }^{5}$ Seeking to still increase its membership, the club launched a membership drive in November of 1924 and set a goal to reach 1000 members. ${ }^{6}$ By 1926, the City Club was one of the largest women's clubs in Louisville. ${ }^{7}$ The club charged a minimum of one dollar for yearly dues in 1918, but it did not discourage members from giving

\footnotetext{
${ }^{3}$ Grace M. Dillman, Emma J. Woerner, Louisville Educator (MA Thesis, U. of Louisville, 1951), 72; The Courier-Journal, 25 June 1929; Louisville Herald-Post, 21 February 1926.

4 “Bulletin: Louisville Women’s City Club,” June 1929, Louise C. Morel Papers, Kentucky Federation of Women’s Clubs Archives, Louisville, KY; Courier-Journal, 25 June 1929.

${ }^{5}$ Courier-Journal, 25 April 1920.

${ }^{6}$ Courier-Journal, 16 March 1924; “The Doubling Campaign,” 1924, Morel Papers.

${ }^{7}$ Louisville Herald-Post, 21 February 1926.
} 
more. ${ }^{8}$ During the 1920 s, the club held monthly luncheon business meetings in addition to social gatherings, such as teas or musical performances to accommodate all its members. $^{9}$

Members of the City Club were active in several fields, and they included the wives and other relatives of Louisville’s most prominent men. One member was Adele Brandeis, a niece of Louis Brandeis, who was active later in compiling Kentucky art for the Works Progress Administration. ${ }^{10}$ The wives of Young E. and Philip E. Allison were both City Club members, as were the wives of James Speed and Lee Bernheim, all wellknown Louisville names. ${ }^{11}$ Mrs. Herman Wischmeyer, whose husband was a local architect, and Mrs. Benjamin Bayless, the wife of a well-known surgeon, were City Club members who were also highly active in the KFWC administration. Two other City Club members, Mrs. J.B. Judah and Mrs. Herbert Mengel, served as president of the Louisville section of the National Council of Jewish Women and president of the Suffrage Association of Kentucky, respectively. ${ }^{12}$ Emma J. Woerner was a respected local educator and became the first principal of Atherton Girls High School. Woerner also served as a president of the Louisville Suffrage Association and was the first and only

\footnotetext{
${ }^{8}$ Courier-Journal, 17 March 1918.

${ }^{9}$ Courier-Journal, 18 April 1925; Louisville Herald-Post, 21 February 1926.

${ }^{10}$ For more information about Adele Brandeis see Brandeis Collection, 1881-1939, University of Louisville Archives, Louisville, KY and “Oral History Interview with Adele Brandeis,” 1 June 1965, interviewed by Harlan Phillips, Smithsonian Archives of American Art, http://artarchives.si.edu/oralhist/brande65.htm.

${ }^{11}$ For more information on the Allison family see Young Ewing Allison Papers, 1878-1943, and Allison Family Papers, 1891-1965, Filson Historical Society, Louisville, KY. For more information on the Speed family see: Speed Family Papers, 1816-1961, University of Louisville Archives, Louisville, KY; Thomas Speed, comp., Records and Memorials of the Speed Family (Louisville, KY: Courier-Journal Job Printing Company, 1892); James Speed Miscellaneous Papers, 1840-1873, Thomas Speed Letter Book, 1863-1896, and Scrapbook, and Speed Family Papers, 1751-1921, and Miscellaneous Papers, 1797-1977, FHS. For more information on the Bernheim family see Isaac Wolfe Bernheim, The Story of the Bernheim Family (Louisville, KY: J.P. Morton and Company, 1910).

${ }^{12}$ National Council of Jewish Women (NCJW) —_Louisville Section, updated 12 August 2003, http://www.ncjwlou.org; Ida Clyde Gallagher Clark, American Women and the World War (New York: D. Appleton and Co., 1918), 272.
} 
president of the Louisville Women's Civic Association before it was disbanded to form the City Club. ${ }^{13}$ Annie Halleck was the first president of the City Club and was also a charter member of the League of Women Voters. Her husband, Reuben Post Halleck, was a textbook author and had been principal of Louisville Male High School for several years. ${ }^{14}$ Other presidents of the City Club included Ethel Lovell, who was the first principal of both the Louisville Prevocational School and the Theodore Ahrens Trade High School, and Mrs. George T. Settle, whose husband was director of the Louisville Free Public Library for eighteen years. ${ }^{15}$ City club members were active women who were involved in several different organizations. The club thrived both because of the members' enthusiasm for the club's work and because of their connections within the community. The women had the money, leisure time, and community respect to achieve the club's reform-oriented goals and to make the city listen to their ideas.

The club met in several places during its first years. The Neighborhood House, a local settlement house, provided meeting space for the City Club during 1917 and $1918 .{ }^{16}$ In 1918 and 1919 the club met at the Young Men’s Hebrew Association (YMHA), perhaps because of the number of prominent Jewish women in the club. ${ }^{17}$ By 1924 the club had relocated to the Bernheim Building; the next year it met at the Brown Hotel. ${ }^{18}$ In 1929, the club held meetings at the Henry Clay Hotel (later known as the YWCA

\footnotetext{
${ }^{13}$ Dillman, 71-72, 80-81.

${ }^{14}$ Patricia Kurtz Bowling, Reuben Post Halleck: A Biography (MA Thesis, University of Louisville, 1968), v-vi, 33-35.

${ }^{15}$ Norma E. Theisen, A Study of the Origin and Development of the Theodore Ahrens Trade School (MA Thesis, University of Louisville, 1942), vii; Works Projects Administration Service Division, comp., Libraries and Lotteries: A History of the Louisville Free Public Library (Cynthiana, KY: Hobson Book Press, 1944), 155.

${ }^{16}$ Courier-Journal, 15 November 1917; Courier-Journal, 16 March 1918.

${ }^{17}$ Courier-Journal, 23 June 1918; Courier-Journal, 30 March 1919.

${ }^{18}$ Courier-Journal, 16 March 1924; Courier-Journal, 18 April 1925.
} 
building). ${ }^{19}$ The reasons behind the often-changing meeting venues are unknown. The club grew large quickly after its inception; perhaps its constant growth required increasingly larger meeting spaces. A new president may have chosen to relocate the meetings to a place convenient to her, or the desirability of the neighborhood might also have had an impact on a proposed meeting space. During its membership drive in 1924, the club touted its "new quarters [the Bernheim Building] in the heart of the shopping district," hoping that potential new members would view the club in as positive a light as they would the city's fashionable shopping district. ${ }^{20}$

Whatever the meeting place, the City Club worked diligently to improve the quality of life for Louisvillians. The City Club women especially were interested in social reform, and even more specifically municipal housekeeping. A program listing the club’s accomplishments and plans for the future mostly consisted of municipal housekeeping activities. ${ }^{21}$ The women stated these interests as the primary goals of the City Club:

The object of this organization shall be to bring together women interested in promoting the welfare of the city; to co-ordinate and render more effective the scattered social and civic activities in which they are engaged; to extend a knowledge of public affairs; to aid in improving civic conditions and assist in arousing an increased sense of social responsibility for the safeguarding of the home, the maintenance of good government, and the bettering of all the conditions surrounding that larger home of all-the city. ${ }^{22}$

\footnotetext{
19 "Bulletin: Louisville Women’s City Club.”

20 "The Doubling Campaign.”

21 "Louisville Women’s City Club,” October 1924, Morel Papers.

22 "Bulletin: Louisville Women’s City Club.”
} 
These goals echoed the goals of other urban women's clubs from the 1890s through the 1930s.

\section{Louise C. Morel}

In 1935, the Louisville Herald-Post described Louise Morel as “a plump and blueeyed little woman, who looks a lot more like somebody’s aunt than she does like...a well-known welfare worker.”23 ${ }^{23}$ et Morel had made a name for herself in Louisville as a crusader for public health, better housing, improved garbage collection, and numerous other social issues. After joining the Louisville Women's City Club in 1917, Morel immersed herself in organizing surveys and campaigns to improve the lives of Louisville citizens.

Louise Charlotte Morel was born in Louisville in 1871 to Peter Henry and Estelle H. Morel. She had two younger siblings, James Seagrove and Sallie. ${ }^{24}$ Morel taught kindergarten around the turn of the century and later edited a medical journal for several years. ${ }^{25}$ These occupations show Morel's early interest in the greater community and health issues, around which she later centered most of her reform work. Morel's fascination with health and the prevention of illness may also have come from her family. Upon his death in 1906, her father worked for the city health department. ${ }^{26}$ Both Morel's mother and brother died of tuberculosis. ${ }^{27}$ Morel dedicated many of her years within the

\footnotetext{
${ }^{23}$ Louisville Herald-Post, 22 October 1935.

${ }^{24}$ United States Census, 1880, Microfilm Collection, FHS; Cave Hill Cemetery Records, FHS.

${ }^{25}$ The New Highlander, 9 March 1929; Louisville Herald, 21 November 1930.

${ }^{26}$ Louisville Death Records, Book 13, page 198, Microfilm Collection, FHS.

${ }^{27}$ Cave Hill Cemetery Records; Louisville Death Records, Book 7, page 99; Louisville Death Records, Book 15, page 114; Sadie Orr Dunbar to Louise Morel, 5 July 1938, Morel Papers. Louise Morel's mother, Estelle, was 58 when she died of "consumption" on 3 October 1888. The city death records state she had suffered with the disease for eight years before passing away. Louise Morel, having been born in 1871, was around nine years old when her mother contracted the disease and was about seventeen when Estelle died. Morel's brother, James Seagrove Morel, died on 23 October 1910 of tuberculosis at the age of thirtysix. Both Estelle and James Morel, along with Louise Morel's father Peter Henry, are buried in an
} 
City Club fighting for prevention of this disease and promoting increased hospital space for tuberculosis patients.

Louise Morel never married, much like other women who dedicated their lives to social reform. She supported herself through various paid positions, both within the City Club and with outside organizations. ${ }^{28}$ By the time she became involved with the City Club, Morel lived with her sister, Sallie, at various times during the 1910s and early 1920s. By late 1928, Morel had moved into a house at 2051 Sherwood Avenue in the Highlands with two other City Club women. ${ }^{29}$ The Sherwood Avenue house had been part of the 1927 Better Homes in America contest of which Morel was the chairperson. ${ }^{30}$ Morel lived at this house through at least the late 1930s, and by 1941 she moved into the Weissinger-Gaulbert apartments at 620 South Third Street. ${ }^{31}$ Sallie Morel married in the mid 1930s and moved with her husband to Johnson City, Tennessee. Louise Morel joined her sister in Johnson City in 1943 when she effectively retired from her career in the City Club, the KFWC, and the GFWC. ${ }^{32}$ Morel joined a Johnson City women's club, the Monday Club, with her sister, and spent the last years of her life in Tennessee. ${ }^{33}$

Morel kept two detailed scrapbooks of newspaper clippings and club publications that mentioned her or her projects. The first scrapbook began when she joined the City Club in 1917, and the second ended in 1956. Very few of the clippings

unmarked family plot in Cave Hill Cemetery in Louisville. See the appendix, page ii, for a picture of the Morel family plot in Cave Hill.

${ }^{28}$ Caron’s Louisville City Directory, 1917-1940, FHS.

${ }^{29}$ Caron's Louisville City Directory, 1928.

30 "Better Homes in America, May 18-15, 1927” flyer, Louise Morel Scrapbook, Morel Papers; "Louise Morel to Club President,” 14 November 1934, Morel Papers.

${ }^{31}$ Letterhead, February 1941, Morel Scrapbook.

32 Johnson City, Tennessee newspaper, 8 January 1935, Morel Scrapbook; Johnson City, Tennessee newspaper, 1943, Morel Scrapbook. Sallie Morel married Robert Wade Taylor. Louise Morel and Sallie Morel Taylor's address in Johnson City was 1101 Southwest Avenue.

${ }^{33}$ Johnson City, Tennessee newspaper, 5 October 1947, Morel Scrapbook. 
from the mid 1940s through 1956 mentioned Morel; most centered around politics, newsworthy events, and items of interest to Morel. The second scrapbook most likely ended upon Morel's death. She would have been about eighty-five years old in 1956.

Morel's career as a social reformer began when she joined the City Club in 1917. Within a very short span of time, she became well-known throughout the city as a reformer. In 1929, the Louisville neighborhood newspaper, The New Highlander, commended Morel's work over the previous ten years, putting her "in the foremost ranks of Louisville’s most progressive citizens.”34

Within the City Club, Morel served in various positions. In 1918, she was appointed as Chairman of the Waste Committee (which headed the garbage separation and disposal survey that year), became chairman of the City Betterment Committee, and served as Field Director throughout the 1920s. ${ }^{35}$ In the KFWC, Morel was elected chairman of the Public Welfare Department from 1926-27 and from 1929-1943, and from 1926-1943 she served as chairman of the Public Health Division of the Public Welfare Department. Morel continued on to become the GFWC Public Health Chairman in the 1940s. ${ }^{36}$

Morel served six years as the local chairman for Herbert Hoover's Better Homes in America program, worked on the White House Conference on Child Health and Protection, and was also a member the Kentucky Tuberculosis Association, the National Board of Social Hygiene, and worked frequently with the Louisville Health

\footnotetext{
${ }^{34}$ New Highlander, 9 March 1929.

${ }^{35}$ Newspaper Article, 15 March 1918, Morel Scrapbook; “City Betterment Aim,” c.1922, Morel Scrapbook; Courier-Journal, c.1920, Morel Scrapbook.

${ }^{36}$ Courier-Journal, 3 February 1940.
} 
Department. ${ }^{37}$ In addition to these responsibilities, Morel appeared to chair just about any project she became involved with, including working for sewer bonds, tuberculosis hospital bonds, and the National Health Exposition shown in Louisville in February of 1922. ${ }^{38}$ From 1921 through 1927, Morel was also a member of another prominent women’s club, the Louisville Woman’s Club. Morel and another City Club member, Lilla Breed, both left the Woman's Club of Louisville in 1927, the same year that club discontinued its affiliation with the KFWC and GFWC because of a dispute over the necessity for individual clubs to support resolutions passed by the GFWC. ${ }^{39}$

Despite all of her offices and chairmanships, Louise Morel accomplished some of her most effective and intriguing work through surveys of the city. The idea of conducting surveys of social and health conditions was not unique to Morel or even to the city of Louisville. The KFWC first proposed the idea in 1915 with a resolution stating:

That when the time is propitious our clubs undertake social surveys and studies of moral conditions in their various communities, with the fixed purpose before them of constant and persistent repression of the social evil as the immediate remedy and absolute annihilation as the ultimate ideal. $^{40}$

\footnotetext{
${ }^{37}$ New Highlander, 9 March 1929; Louisville Herald, 21 November 1930.

38 "Bond Advocates Name Miss Morel," 1925, Morel Scrapbook; "Women to Push Hospital Bonds," 22 October 1922, Morel Scrapbook; “Miss Louise C. Morel,” c.1922, Morel Scrapbook.

${ }^{39}$ Woman's Club of Louisville Yearbooks, 1921 and 1927; Woman's Club of Louisville History, Vol. 1, FHS, 1-4. The GFWC passed a resolution against child labor. The Woman's Club of Louisville did not support the resolution (many of its members were wives of city industrialists), and the club passed their own resolution stating that individual clubs did not need to agree with resolutions passed by the national organization. The GFWC maintained that all affiliated clubs should support national resolutions. Later in 1927, the name of the Woman's Club of Louisville did not appear in the list of GFWC member clubs and the GFWC returned the club's dues, thus ending the Woman's Club of Louisville's affiliation with the GFWC. It is most likely that Morel left this organization because of this incident. Morel was a supporter of the GFWC, working closely with the national organization throughout her career and becoming an officer in the 1940s. Judging from Morel's work to improve the lives of children, she most likely did not support child labor in any form.

40 "Plans of Work,” Kentucky Federation of Women’s Clubs Yearbook, 1915-1916, KFWC Archives, 99.
} 
The writers Mary L. Ely and Eve Chappell recorded that surveys abounded "in the club notes in the Sunday newspaper” in almost every city in the United States. ${ }^{41}$

In Louisville, Louise Morel conducted approximately thirty to forty surveys by the end of her career in additional to all the other work she accomplished through the City Club and the KFWC. ${ }^{42}$ Morel's surveys covered several primary concerns of municipal housekeepers and other city reformers, including garbage collection and separation, the safety and cleanliness of both public buildings and private homes, disease (especially tuberculosis), housing, education and schools, and children's health. After conducting one of her surveys, Morel shared the information with city leaders and other women's clubs. She often encouraged clubs in other towns and states to conduct their own surveys, and she occasionally provided instructions (in the form of her completed surveys) to these clubs. These surveys, and Morel's other projects, show her commitment to Progressive Era-style reform throughout the decades after the so-called end of the Progressive Era.

\footnotetext{
${ }^{41}$ Mary L. Ely and Eve Chappell, Women in Two Worlds (New York: American Association for Adult Education, 1938), 141.

${ }^{42}$ Louise C. Morel, "Surveys Made by the City Club,” c.1929, Morel Papers; “Continuation of Work through the KFWC and GFWC in KY and US," c.1942, Morel Papers; "Surveys Made by Miss Louise C. Morel for Slum Clearance and Other Uses,” 1934, Morel Papers.
} 


\section{CHAPTER FOUR}

\section{THE 1918 GARBAGE DISPOSAL AND COLLECTIONS SURVEY, THE 1920 SANITARY SURVEY, AND SEWER IMPROVEMENT}

The 1918 Garbage Disposal and Collections Survey, the first survey in which Louise Morel participated, and the 1920 Sanitary Survey, the first that Morel conducted, were closely related. The literal "cleaning up” of the city the women hoped these surveys would inspire had long been a goal of city clubwomen. In 1910, the Woman's Outdoor Art League organized “Cleaning Up Days” during April. With the endorsement of James F. Grinstead, Louisville mayor, the women asked Louisville citizens to aid the city’s street cleaning department by collecting refuse from alleys, streets, and yards and placing it in boxes or barrels for the department to collect. ${ }^{1}$ Morel, as chair of the City Club’s Waste Committee, and the women of the City Club continued this kind of "cleaning up" with their first survey in $1918^{2}$

\section{The 1918 Garbage Disposal and Collections Survey}

Louisville passed a city ordinance on 6 October 1917 that required citizens to separate their household garbage into "wet" and "dry" garbage and place it in separate

\footnotetext{
1 “Cleaning Up Days,” 1910, Administration Files 1909-1911, Kentucky Federation of Women’s Clubs Archives, Louisville, KY.

${ }^{2}$ Louisville Herald, 15 March 1918. The City Club changed the name of the Waste Committee to the Sanitary Committee in 1920.
} 
containers. "Wet garbage" consisted of unwanted or spoiled food items. This garbage was to be put in a covered can, and would be used by the city as food for hogs in various places around the city. In order to decrease the number of flies and rats, the city's wet garbage would be kept out of the city dumps. The wet garbage the city collected went to various places. Some of the wet garbage was used as fertilizer for the city's "war garden.” More wet garbage went to a farm near the Home for the Aged and Infirm in Shively (which was once known as the Old Eruptive Hospital). The Louisville Board of Works and the Board of Public Safety announced that the collection of one district's wet garbage would feed seventy-five to one hundred hogs on that farm daily. Hogs kept at the Home and other city-owned properties benefited the residents of these properties as a food source. Wet garbage also fed hogs kept at the city’s Alms House. The city sold yet another portion of wet garbage to other cities and towns for the purpose of feeding their hogs. Selling wet garbage was the most desired outcome - the garbage left the city and the city made a profit from it. ${ }^{4}$

"Dry garbage" was everything that could not be used to feed hogs including ashes, fruit peelings, glass, paper, and cloth. This type of garbage would be collected and placed in one of the city's many dumps, or later, incinerated. ${ }^{5}$ Before the garbage separation ordinance went into effect, many citizens simply dumped their garbage into

\footnotetext{
${ }^{3}$ Ordinance entitled "Separation, Receptacles, etc." in Supplement to Eleventh Biennial Compilation of General Ordinances of the City of Louisville, Including Amendments to City Charter Passed by Legislature, 1917-18 (Louisville: George G. Fetter Co., 1918), 1183-1184; “City Betterment Pledge,” 1920, Louise C. Morel Papers, KFWC Archives.

4 "How to Separate Garbage in Louisville," c.1920, Morel Papers; The Courier-Journal, 2 July 1918 and 7 July 1918.

5 "How to Separate Garbage in Louisville."
} 
one of the city's dumps “overrun with rats, roaches, flies,” or often into a nearby vacant lot, which served as the neighborhood dump. ${ }^{6}$

The city passed the ordinance in 1917, as a direct result of the institution of Camp Taylor that summer. 40,000 soldiers were added in the vicinity of the city, whose "health had to be safeguarded," as Morel put it. ${ }^{7}$ Morel and the City Club believed that a more efficient city garbage collection service was necessary to improve the city and the lives of its residents; a better garbage collection system would "inspire the citizen to a higher standard of community cleanliness.”8 Following these ideals, the City Club worked in cooperation with Samuel Greeley, a “sanitary engineer” from Chicago, Major L.D. Fricks from the US Public Health Service, and city leaders to discuss, gather information on, and create a plan to deal with the city’s garbage problem. ${ }^{9}$

Throughout most of 1917, the City Club’s Waste Committee heard lectures from Greeley and Fricks on garbage collection and garbage disposal possibilities, upon which Greeley conducted a survey of the city. By the end of 1917, the club had begun raising money to conduct their own survey on garbage separation and collection for the city's homes. ${ }^{10}$ The City Club proceeded to raise one thousand dollars, mostly from club members, to conduct a survey on garbage separation and collection in the spring of 1918. The goal of the survey was to inform citizens about the importance of the ordinance. It

\footnotetext{
${ }_{7}^{6}$ Louise Morel, “Ladies and Gentlemen of the Radio Audience...," c.1927, Morel Papers, 1.

${ }^{7}$ Ibid.

${ }^{8}$ Morel, “Garbage Paper,” 1924, Morel Papers, 13.

9 “Annual Report of Waste Committee Made at Annual Meeting of Louisville Women's City Club by Mrs. Lee Bernheim, Chairman of Waste Committee, on March $16^{\text {th }}, 1918$,” Louisville Women's City Club Papers (uncatalogued), Filson Historical Society, Louisville, KY.

${ }^{10}$ Ibid.; "Financial Report of the Louisville Women’s City Club up to Nov. 16, 1917,” LWCC Papers.
} 
also sought to enumerate how many residents complied with the ordinance and separated their garbage, or would agree to do so in the future. ${ }^{11}$

The Garbage Collections and Disposal Survey reflected the ideals of municipal housekeeping. Morel and the clubwomen believed the best way to enforce the garbage ordinance was to ensure that the city’s housekeepers understood it was their responsibility to comply with the ordinance and do their own small part to clean the city as a whole. Armed with this belief, the City Club’s Waste Committee canvassed Louisville neighborhoods by school district to promote garbage separation. ${ }^{12}$ When Mrs. Lee Bernheim, the chair of the Waste Committee, resigned in April of 1918 the City Club elected Louise Morel chair, just in time for Morel to oversee the Garbage Separation survey. $^{13}$

The survey was conducted over two days, 22-23 April 1918. ${ }^{14}$ The women went door-to-door, informed the woman of the house of the city ordinance, gave her a card that described how to separate garbage, and asked her if she would buy cans and separate her household garbage. The Lower Fulton School District is the only portion of the survey existing in City Club collections. Found among Louise Morel's papers, this was most likely the district she canvassed. A small book of lined white paper, covered with a sheet of red construction paper and titled "Point: Garbage," lists the streets and house numbers of the Lower Fulton district. ${ }^{15}$ Starting on Fulton Street and ending with Mill Street,

\footnotetext{
11 “Annual Report of the Waste Committee...”

12 Courier-Journal, 26 October 1919. There were a total of twenty-two districts.

13 “Board Meeting," 3 April 1918, LWCC Papers. Mrs. Bernheim resigned in order to move with her husband to New York.

${ }^{14}$ Louisville Herald, 8 May 1918.

${ }^{15}$ Ibid.; "Point: Garbage,” 1918, Morel Papers. See the appendix, page iii, for a page of this survey. The title of this part of the survey comes from the name of the neighborhood, “The Point.” The Point was originally on a peninsula formed by Beargrass Creek meeting the Ohio River. The city rerouted the creek in 1854, but the area's name remained. Upper class families built mansions and summer homes on the
} 
Morel knocked on every door she found. The homes are listed in sequential order with notes made after each house number. These notes included whether or not the housekeeper intended to purchase garbage cans and separate household garbage, bad housing conditions, the presence of chickens or hogs, and the existence of nearby dumps. In the Lower Fulton district, most of the people with whom she talked indicated they would comply with the garbage separation ordinance. Only a few refused, including one woman on Campbell Street who stated she would not buy garbage cans until the city cleaned her gutters. Morel visited a total of 124 houses and businesses in the Lower Fulton School District northeast of downtown Louisville. ${ }^{16}$

After they conducted the survey the clubwomen gave their results to the city, which used the results in its effort to create a feasible garbage collection plan. ${ }^{17}$ The first collections were to occur three times per week, beginning with the first two neighborhoods on 29 April 1918. ${ }^{18}$ The final districts were scheduled to have organized garbage collection by 10 July $1918 .^{19}$

Not all city residents were enthused about the garbage separation ordinance and the City Club’s drive to enforce it. The most common complaint against garbage separation and collection was the cost incurred through cooperating with the ordinance. Some individual residents were unhappy they were required to purchase garbage cans and

Point, but frequent flooding eventually caused these families to leave the area and therefore opened it up to working class families. By 1918, the year of the survey, the Point was a working class neighborhood. Destruction from the major floods of 1937 and 1945 led the city to condemn the Point. Interstates 64 and 71, Eva Bandman Park, the Louisville Boat Harbor, an apartment complex, and, oddly enough, a city dump all replaced the neighborhood in subsequent years. This information and more about the Point can be found in "The Point" in The Encyclopedia of Louisville, ed. by John Kleber (Lexington, KY: The University Press of Kentucky, 2001), 710-711.

${ }^{16}$ Louisville Herald, 8 May 1918.

${ }^{17}$ Morel, “Garbage Paper,” Morel Papers, 13.

${ }^{18}$ Louisville Herald, 8 May 1918.

${ }^{19}$ Courier-Journal, 23 June 1918. 
then take the time to sort their garbage..$^{20}$ One newspaper article noted the increased cost involved in collecting the garbage twice a week instead of only once as a result of garbage separation. This same article asked if the enforcement of the garbage separation and collection ordinance was not causing difficulty in the form of financial problems for the city's street cleaning department. The article quoted Morel's response, which stated that the City Club would investigate this charge and urged citizens not to "condemn the new garbage separation plan...without a full knowledge of the facts.” ${ }^{21}$

The City Club backed garbage separation despite any increased cost to the city; the women believed that the health of the city's people was worth a larger financial cost to the city. However, the women did not fully acknowledge the inability of poor citizens to purchase multiple trash cans. For the city’s poor, it was much less expensive to seek out a nearby dump in which to dispose of their garbage. Many of these same people were the ones who kept hogs on their own property, most likely as food or to sell for money. Those who kept hogs preferred to keep their wet garbage to feed these hogs, which was easier and more economical than separating it for the city to collect.

The completion of the City Club’s Garbage Separation Survey did not end Morel's or the club's general interest in maintaining and improving Louisville's garbage collection system. One year after the women finished the survey and the city began enforcing separation, Morel stated that garbage separation and the improved methods of garbage collection and disposal had greatly improved city residents' quality of life. ${ }^{22}$ Of course there were those residents who continued to refuse to cooperate with the ordinance. These people instead opted to burn their own garbage, kept their wet garbage

\footnotetext{
20 "Point: Garbage."

${ }^{21}$ Courier-Journal, 16 March 1919.

${ }^{22}$ Courier-Journal, 30 March 1919.
} 
for feeding their own hogs, or simply did not separate their wet and dry garbage for collection. The City Club urged all residents to act in accord with the garbage ordinance, and welcomed the city's decision to fine citizens who did not separate their garbage beginning on 27 January 1919. ${ }^{23}$ An ordinance passed in 1922 that outlawed keeping hogs within certain areas of the city limits further enforced the garbage separation ordinance by giving citizens no reason to keep their wet garbage. ${ }^{24}$

By at least 1922, Morel and the City Club women renewed an earlier effort to build city incinerators, hoping to eliminate the need for dumps altogether. City Club women and other reformers complained specifically about unhealthy conditions caused by a city dump present at Rowan Street and Twenty-Eighth Street, and cited it as an example of all city dumps. ${ }^{25}$ City leaders agreed with Morel and the clubwomen, and by 1924, had made plans to build two incinerators, one each in the city's West and East Ends. By 1928, the city had one functioning incinerator in the West End and one under construction in the East End, and Morel began campaigning for yet a third incinerator to dispose of garbage from downtown and the South End of Louisville. ${ }^{26}$ Again, Morel proposed this third incinerator in the hopes of eliminating the remaining city dumps. She maintained that the one working incinerator could not possibly dispose of the entire city's garbage. Therefore most residents continued to rely on city dumps to collect their garbage. She gave an example of a dump that existed on Barrett Avenue in the Highlands which collected dry garbage from all sections of the city save the West End.

\footnotetext{
${ }^{23}$ Courier-Journal, 26 January 1919.

${ }^{24}$ Ordinance entitled "Animals: Hogs, Sheep, and Goats-Prohibiting the Keeping in Certain Limits" in Compilation of General Ordinances of the City of Louisville (Through December 31, 1923) (Louisville: n.p., 1923), 22-23.

${ }^{25}$ The Louisville Times, 25 June 1924.

${ }^{26}$ Morel, "Ladies and Gentlemen of the Radio Audience...," 2.
} 
Those who lived near the dump were poor and were subject to the odors and rodents that accompanied the dump's presence. ${ }^{27}$ The completion of the East End incinerator and the addition of a third incinerator would eradicate the need for dumps and thereby improve the lives of those who lived near the dumps.

The City Club women's concern with the collection and disposal of garbage was not unique. The members of the Chicago Women's City Club worked with similar issues during the 1910s. The Chicago club wanted the city to take control of garbage collection from the private company that was contracted to collect Chicago's garbage. The club also proposed incineration as a cleaner alternative for destroying garbage than the reduction method supported by many of the city’s businessmen. Like the Louisville City Club, the Chicago club emphasized health and cleanliness over profits and costs. The Chicago women were successful as municipal ownership of the city’s garbage collection was instituted in $1914 .^{28}$

\section{The 1920 Sanitary Survey}

The issue of garbage separation and collection inspired the Louisville Women's City Club’s Sanitary Survey of 1920, because as Morel stated, “many other disgraceful and unsanitary conditions were found” during the Garbage Collection Survey. ${ }^{29}$ Morel's goals with the Sanitary Survey included: finding and recording every occurrence of what the women deemed unsanitary within the city; having these problems righted by existing city ordinances, or campaigning for new ordinances to address unsanitary issues; and educating city residents on keeping their homes and yards clean and healthy. Again, for

\footnotetext{
${ }^{27}$ Newspaper clipping, 10 September 1927, Louise Morel Scrapbook, Morel Papers.

${ }^{28}$ Maureen A. Flanagan, “Gender and Urban Reform: The City Club and the Woman's City Club of Chicago in the Progressive Era,” The American Historical Review 95 (October 1990): 1036-1039.

${ }^{29}$ Morel, "Ladies and Gentlemen of the Radio Audience...," 2.
} 
the purposes of conducting the survey, the city was divided along school district lines into approximately forty districts. Each district was assigned a chairperson and a committee of investigators composed of City Club members, other clubwomen, and interested volunteers from other civic organizations. Members of the committees covered their districts by city blocks, visiting each home and business on a block. Surveying a single district took approximately one to two weeks. ${ }^{30}$

Investigators were directed to look for eleven specific conditions at each lot they visited, either by sight or through discussion with the woman of the house. All of the items investigated were covered by city ordinances enacted from the years 1893 through 1917, except one (which would be in 1922). The problems investigated were as follows: ${ }^{31}$

- Stables. Were they kept clean? Was manure properly disposed of so as not to attract flies and rats and give off odors?

- Street Wells and Pumps. Were the pumps removed? Were the wells sealed if Health Department investigations found the water in them to be polluted?

- Garbage. Was garbage separated into wet and dry? Was it contained in cans and covered well?

- Vault or Yard Toilet. Were these closed? Were houses using either sewers or septic tanks?

- Sewers. Were homes with access to sewers connected to them?

\footnotetext{
${ }^{30}$ Morel, “The Louisville Sanitary Survey,” The Club Woman (December 1923), KFWC Archives, 7; Morel, "Sanitary Survey Summary," c.1923, Morel Papers, 1.

${ }^{31}$ Morel, "Ladies and Gentlemen of the Radio Audience...," 2-3; "City Betterment Pledge”; Morel, “Sanitary Survey Summary,” 1.
} 
- Private Dumps. Were any of these present on the city block? Were the residents using a private dump instead of putting their garbage out for removal to a city dump?

- Dirty Premises or Yards. Was the home or yard littered with garbage? Was the home dirty?

- Vacant Lots. Were these present? Could they be converted into community gardens?

- Housing. Was the house connected to the sewer lines? Did it have running water? Were there enough windows to allow light and ventilation inside the house? Was the house dirty or in disrepair? Was it overcrowded?

- Unsanitary Groceries. Were nearby bakeries, dairies, meat markets, and other places preparing or selling food clean and well-maintained?

- $\quad$ Streets and Alleys. Were the block's streets, alleys, sidewalks, and gutters free of litter and in good repair? ${ }^{32}$

If investigators noted any of these eleven conditions on or around the property they visited, they wrote them down on the pledge described below for further investigation by the Health Department or other relevant city department. The City Club’s Waste Committee most likely composed the wording of the pledges, although they may have worked in close connection on the wording with the city's Board of Works, which paid to have the pledges printed for the City Club. ${ }^{33}$

\footnotetext{
32 Morel, “Sanitary Survey Summary,” 1-2; Morel, “The Sanitary Survey,” 7.

33 “Board Meeting, September 25, 1919," LWCC Papers; “Board Meeting Minutes, January 8, 1920,” LWCC Papers.
} 
As with the Garbage Separation Survey, the items listed as problems in the Sanitary Survey revealed class differences between the City Club women and those whose properties they sought to improve. The city’s poor lived in overcrowded homes with little ventilation. They could not afford to buy trash cans in which to separate garbage, they were most likely to be using an outhouse rather than a sewer-connected toilet, they did not have access to city water, and they did not have the time to keep their homes or yards clean. The clubwomen came from middle and upper class families. They saw the conditions in which the poor lived and sought to rectify these conditions to their own middle-class standards. The City Club women wanted to give the poor "better" lives by improving their surroundings.

The clubwomen and volunteers gave each household they visited a City Betterment Pledge, which the household member signed and stated which items listed on the pledge she intended to observe. The twelve items listed on the pledge ranged from "I will not use vacant lots as a dumping ground" to "I will aid in any way I can to exterminate the house fly."34 Most, however, were solutions to rectify the eleven conditions for which the survey's investigators were looking. Almost all pledge items were supported with cited city ordinances. After signing, the housekeeper kept the section of the pledge that described the ways to better the community, and the clubwomen kept the signed section. On the reverse of the signed part of the pledge, the investigator could note which of those eleven unsanitary conditions were present at or around that particular property. These would later be investigated by a city sanitary inspector. $^{35}$

\footnotetext{
34 "City Betterment Pledge." See the appendix, page iv, for a copy of the City Betterment Pledge.

35 “City Betterment Pledge”; Morel, “Sanitary Survey Summary,” 2.
} 
Following the investigatory part of the survey, Morel, the other women, and volunteers compiled lists of all unsanitary conditions they found throughout the city. Each list was labeled with its offense, "Vacant Lots” or “Unsanitary Groceries,” for example. Under each heading, the women listed all properties found in violation. On district maps, drawn by students at the Boys’ Dupont Manual Training High School, the clubwomen used colored pins to note every sanitary violation in the city. On another set of district maps the women used colored pins to locate births and deaths, and more specifically, the causes of deaths. Louisville's Health Department furnished these statistics. The district maps enabled the women to locate possible connections between unsanitary conditions and deaths. ${ }^{36}$

After completing the lists and maps, the women reinvestigated each violation. If it no longer existed or had been improved, its corresponding pin was removed from the map. If the problem persisted, it was reported to Morel who then contacted the appropriate city department. A city sanitary inspector was then dispatched to the property to inform the resident of his or her violation. If the problem was not righted within a certain amount of time, the resident was charged with violation of a city ordinance and brought to court. If the resident was a tenant, it is unclear whether the tenant or the owner of the home was charged with violating a city ordinance. Morel noted that few cases went to court, as a visit from a city official was motivation enough for most people to improve the conditions of their home or yard. However, when a case

\footnotetext{
${ }^{36}$ Morel, "The Louisville Sanitary Survey,” 7; Morel, "Sanitary Survey Summary,” 2. See the appendix, page v, for a part of the Lower Fulton district map.
} 
did go to court, the clubwomen who had originally inspected the property were often called upon to provide testimony. ${ }^{37}$

The City Club worked to inform the city of existing problems, helped the city to remove these problems, and educated the public on city laws. Through reporting violations and seeing that these reports were followed by some sort of action, the City Club acted as an unelected arm of the city government. This was not unusual for women's clubs that worked as municipal housekeepers. The women of the City Club believed it was their duty to act as an unpaid liason between the people of the city and the city government. They also believed it was their duty to aid the city in enforcing ordinances through reporting violations, which often resulted in fines for residents. In addition, the club conferred with the mayor and other city government representatives. The representatives accepted the women's involvement and sometimes provided aid in the form of materials or simply a verbal acceptance of the City Club’s work.

According to Morel, most women who were surveyed agreed to sign the City Betterment Pledge, which she described as "City Law clothed in plain language." 38 The Sanitary Survey exemplified a primary belief of municipal housekeepers--the individual citizen must care about keeping sanitary conditions before the city could become a healthier place. With this survey, Morel asserted that the clubwomen had gone directly to the city's housekeepers and asked them to "sweep before their own doorsteps."39 Each individual woman must care for her own home; if she did, then women as a whole could care for the entire home community. Morel strongly believed in this theory, and

\footnotetext{
${ }^{37}$ Morel, "Sanitary Survey Summary,” 2.

${ }^{38}$ Courier-Journal, 2 July 1922; Morel, “Sanitary Survey Summary,” 2.

${ }^{39}$ Newspaper clipping, c.1922, Morel Scrapbook.
} 
proceeded to encourage the city's women to take responsibility for their own homes and property in order to work for a cleaner and healthier city.

The results of the sanitary survey were widespread. The most direct result was the creation of a City Complaint Department, which was widely used by Louisville citizens to report unsanitary and hazardous conditions in the city. After investigation and reports to the Health Department, the City Club women were able to correct many of these conditions. ${ }^{40}$ Education was another result of the survey. After the district maps were completed, the women made copies and distributed them to teachers interested in teaching their classes about the project. Through the maps' use in the classroom, children learned how to find and correct unsanitary situations, why these problems needed to be corrected, and even how the city government functions in response to unsafe conditions in the city. ${ }^{41}$

The City Club’s Sanitary Survey was such a success that copies of the finished product and instructions on how to complete the survey were sent, by request, to women's clubs in other towns and cities in Kentucky, the surrounding region, and cities farther away including Dallas, Boston, Chicago, and Orlando. ${ }^{42}$ The General Federation of Women's Clubs endorsed plans for individual clubs to conduct sanitary surveys based on Morel's. ${ }^{43}$ Morel wrote these instructions and often gave lectures at club meetings to persuade other clubs to conduct their own sanitary surveys. ${ }^{44}$

\footnotetext{
${ }^{40}$ Morel, "Ladies and Gentlemen of the Radio Audience...," 3.

${ }^{41}$ Morel, "The Louisville Sanitary Survey," 7.

${ }^{42}$ Morel, "Ladies and Gentlemen of the Radio Audience...," 4; Chicago Women's City Club Bulletin, January 1923, Morel Scrapbook.

${ }^{43}$ Louisville Women’s City Club publication, October 1923, Morel Scrapbook.

${ }^{44}$ Lexington Herald, 28 September 1921; Danville Kentucky Advocate, 2 January 1925.
} 
As a result of the sanitary survey, Louisville leaders introduced several new ordinances to correct unsanitary conditions that had not been addressed by existing ordinances. One of these ordinances, occurring as a direct result of the 1918 and 1920 surveys, banned people from keeping hogs year-round within city limits. ${ }^{45}$ The women conducting the 1918 garbage separation survey often had counted how many households kept hogs and other animals, and also noted complaints against the animals, which usually referred to the odor of the hogs. ${ }^{46}$ The Women's City Club prepared and supported the 1922 city ordinance against hogs in the city and backed prosecution of those who violated the ordinance. ${ }^{47}$

The City Club’s backing of the hog ordinance again indicated class differences between the clubwomen and those who kept hogs in the city. Seeing only the filth and odor that came from keeping hogs, the City Club women believed that banning them from the city was the best way to improve the lives of citizens. Those who kept hogs, however, most likely chose to do so for financial and food reasons. One newspaper article noted the City Club’s approval of the prosecution of two men who lived in the working class Point neighborhood and had continued to keep hogs despite an older city ordinance that prohibited the keeping of hogs within the city during summer months. ${ }^{48}$ Although the clubwomen wanted to help the poorer neighborhoods like the Point combat disease and dirty living conditions by banning hogs, they also hurt the working class by taking away a major resource.

\footnotetext{
${ }^{45}$ Morel, "Ladies and Gentlemen of the Radio Audience...," 3; Courier-Journal, 18 June 1921; Ordinance entitled "Animals: Hogs, Sheep, and Goats—Prohibiting the Keeping in Certain Limits," 22-23.

46 "Point: Garbage."

${ }^{47}$ Courier-Journal, 18 June 1921 and 2 July 1922.

${ }^{48}$ Courier-Journal, 18 June 1921.
} 


\section{Sewer Improvement}

Sewer improvement was another result of the sanitary survey. Lack of sewer service to certain areas and homes that were not connected to available sewers were two of the items the women looked for while conducting the survey. Louisville had been struggling with inadequate sewers for several years before Morel and the City Club began their campaign. Voters passed the first sewer bond in 1906. As a result, the city created and appointed members to the Commissioners of Sewerage who were to direct when and where new sewers were to be built. The city successfully built new sewers until 1915. By 1919, the Commissioners reported that they needed more money in order to continue the sewer work, and voters passed another bond, worth $\$ 2,000,000 .^{49}$ By 1923 , residents such as Morel and the City Club women discovered the city needed additional funds in order to build more sewers, as the city again had outgrown its existing sewer system.

In 1923 Louisville had approximately three hundred miles of sewers, which were no longer enough to serve the entire city. Morel and the City Club women also wanted the sewer system expanded to serve newly annexed sections of the city that had no sewer service at all. ${ }^{50}$ Some of the oldest sections of the existing sewer lines in 1923 were built in 1850. Morel wrote that these older parts of the sewer system were too small to handle the amount of sewage they were then required to contain in 1923. If the city expanded the sewer system, the older sections would be unable to take on any additional sewage from newer parts of the city. Morel also noted that when certain parts of the city received a large amount of rainfall, the sewers overflowed and the streets flooded. In addition to

\footnotetext{
${ }^{49}$ Metropolitan Sewer District (MSD) History, Louisville, KY, http://www.msdlouky.org/aboutmsd/history.htm.

50 "Sewers in Louisville," 1923, Morel Papers, 2; Ordinance entitled "Territory in Jefferson County" in Compilation of General Ordinances of the City of Louisville (Louisville: The Standard Printing Co., Inc., c.1920), 24-28.
} 
pushing for construction of new sewers, Morel wrote that it was essential for both old and new sewers to be cleaned at least once a year in order for the sewers to continue working properly. $^{51}$

Although she was one of the most vocal, Morel was not alone in her support for an improved sewer system. In 1924, the Commissioners of Sewerage of Louisville sent a letter to city residents, in which they described the immediate need for the construction of more sewers in Louisville. The letter stated that forty-six percent of the city did not have sewers. It also cited such unhealthy conditions as overflowed sewage pits in the East End, sewage-flooded homes and businesses in the West End and downtown, and sewagepolluted streams that children play in throughout the city. In response to the sewer problems, the Louisville Board of Public Works decided to suspend building new streets until the areas that needed these streets had sewer connections. The letter implied that once a neighborhood had sewer access, its residents would enjoy new streets and nice homes and increased property values. The point of the letter was to encourage citizens to vote for a $\$ 5,000,000$ sewer bond in November 1924 . The City Club had campaigned for this bond for over a year. The letter was endorsed by several Louisville citizens including Louise Morel, whose name appeared with others at the end of the letter. ${ }^{52}$

The passage of the $\$ 5,000,000$ sewer bond in 1924 did not provide sewer access to the entire city. In the mid-1920s, two-thirds of the city was connected to the sewer lines, but there were still several areas without service. Therefore, in the following years,

\footnotetext{
51 "Sewers in Louisville," 1-2. Morel also indicated that the type of pavement used on the streets contributed to the overflow of sewers. Instead of a pavement that could absorb water, the streets were constructed of a pavement that repelled water. This forced the water into the sewers, causing overflow. Morel urged a new kind of construction for the streets that would absorb water.

52 "Commissioners of Sewerage of Louisville to All Citizens of Louisville," 1924, Morel Papers; CourierJournal, 12 October 1924.
} 
Morel and the City Club women actively supported a \$10,000,000 sewer bond. ${ }^{53}$

Morel's work was successful, as the 1928 sewer bond passed and allowed for more sewer construction in Louisville.

In the tradition of the municipal housekeeper, Morel appealed to mothers’ concerns for their children's health. Morel used this tactic in campaigning for the 1924 sewer bond. She spoke to groups of children at schools and impressed upon them the need for the entire city to be served by adequate sewers. Morel most likely had several reasons for speaking to children about the city’s sewer problems. One was a genuine desire to educate children in civic affairs, especially those relating to the interests of the municipal housekeeper. Morel was, after all, a former kindergarten teacher. She was also a municipal housekeeper interested in helping children and addressing problems that most often affected women and children. Another reason was the opportunity to impart her opinions to the children who would, in turn, relay this information to their parents at home. This reason is evident in a child's letter to a Louisville newspaper in 1924. The child wrote about Morel's visit to her class, detailed why the city needed new sewers, and urged all Louisville mothers to vote for the sewer bond. ${ }^{54}$

As she did with many of her projects, Morel revisited the sewer issue occasionally after 1928. Sewers posed a problem again during the 1937 flood, as Morel noted in a speech she gave to a Johnson City, Tennessee women's club. She emphasized the unsanitary conditions of the Louisville sewers, which she believed worsened the flooding problem by releasing polluted water into the streets. ${ }^{55}$

\footnotetext{
53 “Summary of Accomplishments of Public Health Department under Miss Louise Morel,” c.1938, Morel Papers.

54 Newspaper clipping, 1924, Morel Scrapbook.

55 Johnson City Press-Chronicle, 31 January 1937.
} 
There were occasional reoccurrences of sewer problems, unseparated garbage, illegal dumps, and several other problems found in Morel's surveys. Morel and the other women realized that these problems would not be solved overnight, and they continued to work to eradicate unhealthy and unsafe conditions in Louisville long after the surveys were completed and the problems were first addressed. Although Morel and the City Club found many other issues to address during the next two decades, they continued to work on these early problems of garbage and other unsanitary conditions in the city, and sewer connections. 


\section{CHAPTER FIVE}

\section{THE 1922 HEALTH EXPOSITION, THE 1924 HOUSING SURVEY, AND TUBERCULOSIS HOSPITALS}

One of Louise Morel's primary concerns was public health. She served seventeen years as the KFWC public health department chair and even held this position at the national level within the GFWC during the 1940s. Morel's concern in preventing the spread of disease through education and promoting better care for those afflicted may have stemmed from personal experience with tuberculosis, a disease that affected both her mother and her brother. Although tuberculosis was perhaps the most important health issue to Morel, she also spent time educating the public and helping those affected by numerous other illnesses.

Morel and the other City Club women worked often to improve the health of children. Children's health and general care had always been one of the foremost concerns of municipal housekeepers all over the country. Settlement house workers founded day cares and urged the building of playgrounds. ${ }^{1}$ The women who ran the Children's Bureau devoted themselves to the welfare of the country's children. Reformers in most cities concentrated on improving schools and founding kindergartens. The desire to improve children's lives was no different in Louisville.

\footnotetext{
${ }^{1}$ Allen F. Davis, Spearheads for Reform: The Social Settlements and the Progressive Movement, 18901914 (New York: Oxford Press, 1967), 45-46.
} 
In the 1920s, Morel promoted contributions to the Maternal and Child Health Bureau, a division of the state Board of Health. ${ }^{2}$ That same year, in her position as Public Health chair, she urged Kentucky clubwomen to campaign for school health exams. ${ }^{3}$ Morel attended the White House Conference on Child Health and Protection in November 1930. ${ }^{4}$ In 1935, Morel advocated immunization against diphtheria. Using colorful military terminology, Morel wrote to Kentucky clubwomen, "War is declared against DIPHTHERIA, the most vicious enemy of childhood...gather your forces for the battle...it's up to the women.”5 In the late 1930s and early 1940s, Morel implored Kentucky clubwomen to observe May Day as a day dedicated to improving children's health. The May Day campaign was national, and Morel worked to organize local programs to educate parents on immunization and other child-related health issues. ${ }^{6}$

Although children's health was a primary concern of Morel's, she sought to educate the public on several other health issues including cancer, sexually transmitted diseases, and especially tuberculosis. Morel had wide support from the city’s government officials, business leaders, and the influential clubwomen. Her organization of the 1922 Health Exposition, the 1924 Housing Survey, and her campaign to improve Louisville's tuberculosis hospitals show Morel's interest in public health and her continued cooperation with community leaders.

\footnotetext{
2 “Lebanon, Ky., Mass Meeting,” 15 February 1926, Louise C. Morel Papers, Kentucky Federation of Women’s Clubs Archives, Louisville, KY; “The State Board of Health of Kentucky,” c.1930, Morel Papers.

3 "Louise Morel to Clubwomen,” 27 February 1929, Morel Papers.

${ }^{4}$ Louisville Herald, 21 November 1930.

5 "Louise Morel to Clubwomen,” 27 April 1935, Morel Papers.

6 “Louise Morel to Clubwomen,” 31 March 1938, Morel Papers; "Louise Morel to Club President,” 1941, Morel Papers; “Louise Morel to Club President,” 10 April 1942, Morel Papers.
} 


\section{Health Exposition}

The first Health Exposition in Louisville was held the first eleven days in February 1922 at the Armory. Holding a Health Exposition was Morel's idea, which she first proposed at a City Club meeting a year or two earlier. ${ }^{7}$ The following year, Morel and other City Club members worked with the Health Department put together a small exhibit that was shown at the State Fair. The success of that exhibit prompted the City Club to allocate two thousand dollars toward planning an exposition dedicated to educating the public on health issues. ${ }^{8}$

In planning the Louisville Health Exposition, Morel traveled to New York City to discuss plans for the exposition with the Russell Sage Foundation and to find "some man” to take control of the business aspects of the exposition; R.E. Logsdon took this position. ${ }^{9}$ A committee was formed and another man, Frank Hartwell, was named chair of the entire exposition. Morel, however, retained control over supervising the exposition. She visited a health exposition held in Cincinnati, and modeled the Louisville exposition after similar expositions in Cincinnati, Chicago, and New York. ${ }^{10}$ The City Club had the cooperation of several local and state organizations. The state, county, and city Boards of Health, the Louisville Board of Trade, the Louisville Board of Public

\footnotetext{
${ }^{7}$ Louise Morel, “Health Exposition 1922,” 1922, Morel Papers, 1; Louisville Herald, 10 February 1922. These are two different accounts of when Morel first proposed the idea of a health exposition. In the report entitled "Health Exposition 1922" Morel wrote she first mentioned the idea in July 1920. The Louisville Herald article stated that Morel thought of holding a health exposition in April 1921 while she was chair of the City Betterment Committee.

${ }^{8}$ Louisville Herald, 10 February 1922.

${ }^{9}$ KFWC Bulletin, April 1922, Louise Morel Scrapbook, Morel Papers; Louisville Herald, 10 February 1922.

${ }^{10}$ KFWC Bulletin, April 1922; Morel, “Health Exposition 1922,” 1; Courier-Journal, 29 January 1922.
} 
Safety, and the Louisville Auto Club worked with the City Club in organizing the exposition. $^{11}$

The exposition cost more than fifty thousand dollars, but the exposition was such a success that it turned a profit, which was split between the City Club and the Louisville School of Public Health. The City Club and the other groups involved financed the exposition through selling admission tickets and selling three hundred booth spaces to interested parties. Organizations purchased as many spaces as they needed to set up their exhibit. Exhibitors included the Louisville Health Department, the University of Louisville, the University of Kentucky, the Boy Scouts of America, the Red Cross, the Women’s Christian Temperance Union, the Young Men’s Christian Association, the Kentucky Child Labor Association, Waverly Hills Tuberculosis Sanitarium, the Louisville Public School system, the Dental Association, and the City Club, among several others. $^{12}$

The Health Exposition offered the City Club a perfect opportunity to share its findings from the Sanitary Survey with the public. The club set up a booth with statistics from the Sanitary Survey and photos of poor conditions around the city displayed. Morel herself saw the exposition as the perfect place in which to educate citizens on sanitary and public health issues. She shared this opinion with the Civic Journal in 1921: "The city does not realize how dirty it is. It is our belief that if we can show people-make them visualize conditions — that we shall be able to improve them."13

\footnotetext{
${ }^{11}$ Louisville Herald, 10 February 1922. Both the Filson Historical Society and the University of Louisville library and archives have various pieces of information about these organizations, but none reference their involvement and support of the 1922 Health Exposition.

${ }^{12}$ Courier-Journal, January 1922; Morel, “Health Exposition 1922,” 3-4.

${ }^{13}$ Civic Journal, March 1921; Courier-Journal, 29 January 1922.
} 
Morel believed the general public attended the exposition because it was entertaining. She acknowledged that most people were not interested in learning about health issues through pamphlets and lectures. The health exposition promised a new form of entertainment that also happened to teach the public. Morel called the exposition "painless education."14 She and the organizers gauged the city’s interest correctly; over one hundred thousand people visited the exposition. ${ }^{15}$ Many came on designated days, such as Club Day, Kentucky Day, or High School Day. Exposition organizers declared the first day of the exposition Public School Day. Visitors on every day of the exposition learned about health issues and preventive measures at booths sponsored by organizations and lectures given by physicians and other health professionals who came to the exposition from all over the country. Politicians such as Louisville’s mayor Huston Quin gave speeches about the law and health issues. Exposition visitors also learned about health issues through plays, short films, and demonstrations. ${ }^{16}$

The Health Exposition in 1922 was a culmination of Morel's early work with the City Club. The exposition encompassed Morel's primary goal—educating the public on health and sanitary matters. Even with the help of the City Club, Morel could not have reached as many people as did the Health Exposition. The exposition was successful because of Morel's work in planning it, securing the cooperation of local organizations, and persuading other individuals to become involved in organizing the exposition. The Health Exposition of 1922 was a success and was held again in following years. ${ }^{17}$

\footnotetext{
${ }^{14}$ Morel, “Health Exposition 1922,” 2.

${ }^{15}$ Louisville Herald, 10 February 1922.

${ }^{16}$ Courier-Journal, 9 February 1922; Morel, “Health Exposition 1922,” 3.

${ }^{17}$ Courier-Journal, 9 February 1922; Courier-Journal, 10 March 1923.
} 


\section{Housing Survey and Tuberculosis Hospitals}

Tuberculosis was a disease with which Louise Morel had personal experience.

Both Morel's mother and brother struggled with tuberculosis and died from the disease. ${ }^{18}$

Morel worked to educate the public on the prevention of tuberculosis and sought to improve Louisville’s tuberculosis hospitals throughout her career. Morel and the City Club conducted a Housing Survey in 1924 in order to pinpoint housing problems that might have led to inhabitants’ contracting tuberculosis. After gathering these statistics, Morel used them to educate the public on ways to prevent tuberculosis. Throughout the 1920s and into the 1930s, Morel focused on campaigning for bonds that would be used to improve the city's two tuberculosis hospitals, Hazelwood and Waverly Hills. Much of Morel's work on tuberculosis was accomplished through cooperation with the clubwomen of the KFWC.

The women of the KFWC had fought against tuberculosis for several years. It was especially emphasized during the administration of Mrs. James Leech (1909-1911). Caroline Leech spoke to schoolchildren about tuberculosis and taught them how to prevent the disease with exercise and proper ventilation. ${ }^{19}$ Before leaving, Leech would give the children stickers that explained the prevention of tuberculosis to paste in their spelling books. The stickers were placed in spelling books because children often took these books home, and the women hoped the children's parents would take notice of the sticker and encourage their children to follow its suggestions. The clubwomen dubbed this effort the Spelling Book Crusade and carried it throughout the state. With this

\footnotetext{
18 “Sadie Orr Dunbar to Louise Morel,” 5 July 1938, Morel Papers; “Irene Carroll to Louise Morel,” 15 March 1939, Morel Papers.

19 “Frank McKee Greer to Mrs. Leech,” 26 January 1910, Administration Files 1909-1911, KFWC Archives; “J. Harold Meyer to Mrs. Leech,” 28 January 1910.
} 
crusade, Leech and the KFWC women hoped to hinder the spread of tuberculosis among children. $^{20}$

In 1916, one-third of deaths in Kentucky resulted from tuberculosis, and the clubwomen, beginning in Mrs. Leech’s administration, feared many of these were children, as exemplified in this poem from the 1921-1922 KFWC yearbook: ${ }^{21}$

It's a hard fight to save the children;

It's a hard fight, we know.

It's a hard fight to save the children, But the fiend Disease must go.

Come, men, for hearth and homeland, play up, do your share, It's a hard fight to save the children;

But Kentucky's right there. $^{22}$

Despite the dramatic increase in deaths from tuberculosis in Louisville during the 1910's, the state's tuberculosis hospitals were overcrowded and were turning patients away. Even before the housing survey in 1924, Morel had worked tirelessly for a hospital bond in 1922 in order to improve one of the two existing tuberculosis hospitals in Louisville. ${ }^{23}$

At that time, the Waverly Hills Tuberculosis Sanatorium, a public hospital for residents of Jefferson County, in south Louisville was filled beyond capacity. The hospital received donations from the Louisville Tuberculosis Association which sold Christmas Seals each year to raise funds for the hospital. ${ }^{24}$ This fundraising, however, could not provide for the hospital's expansion. In 1922, the City Club women, under the direction of Morel, campaigned for a $\$ 750,000$ bond that would enable Waverly Hills to

\footnotetext{
${ }^{20}$ Tuberculosis Book Mark, c.1910, Administration Files 1909-1911; “Spelling Book Crusade On,” c.1910, Administration Files 1909-1911.

21 “Health,” Kentucky Federation of Women’s Clubs Yearbook, 1916-1917, KFWC Archives, 40; Morel, "Tubercular Children of Kentucky,” c.1924, Morel Papers.

22 "Report of Health Department," Kentucky Federation of Women’s Clubs Yearbook, 1921-1922, 89.

${ }^{23}$ Courier-Journal, 22 October 1922.

${ }^{24}$ Anna J. Haines, Tuberculosis in Louisville and Jefferson County (MA Thesis, U. of Louisville, 1943), 40, 43. The Filson Historical Society has a small collection of the Louisville Anti-Tuberculosis Association's (later renamed the Louisville Tuberculosis Association) minute books and financial records.
} 
build a new, larger hospital. The state built the original Waverly Hills sanitarium in the first years of the twentieth century and intended it to hold forty patients. By 1922, two hundred patients were housed in the hospital with 2600 more on a waiting list. ${ }^{25}$ The hospital was in poor condition; a newspaper article from 1922 stated "the buildings have been condemned as fire traps." 26

Morel used several tactics to urge people to vote for the bond. City Club members sold tickets to the US Army Air Circus show held in June 1922 at Bowman Field, from which part of the proceeds would fund an advertising campaign promoting the bond. Morel worked with women from eighty local women's organizations on a Tuberculosis Committee on which she served as Organization Chair. The committee worked to gather volunteers to be ward captains, women who worked within their designated ward to urge citizens to vote for the bond. ${ }^{27}$ Morel organized 1400 women who worked at the polls on Election Day to ensure the passage of the hospital bond. ${ }^{28}$ After the bond passed in 1922, construction began in the spring of 1923 to build the new hospital that would hold almost 500 patients. ${ }^{29}$ Morel and the City Club women recognized the extent of the tuberculosis problem in Louisville and sought to get to the root of it, prevention of the disease, through the housing survey.

Morel conducted the housing survey in 1924. The reasoning behind the housing survey was, as Morel stated in 1924, the housing "conditions that prevail are a menace to health.” She indicated that improved housing would lead to improved health. ${ }^{30}$ Morel

\footnotetext{
25 “The Doubling Campaign,” 1924, Morel Papers; Newspaper clipping, 1922, Morel Scrapbook.

${ }^{26}$ Newspaper clipping, November 1922, Morel Scrapbook.

${ }^{27}$ Courier-Journal, 22 October 1922.

${ }^{28}$ Newspaper clipping, November 1922, Morel Scrapbook.

29 “The Doubling Campaign.”

${ }^{30}$ Newspaper clipping, 1924, Morel Scrapbook.
} 
and the City Club members believed that poor home conditions might cause tuberculosis to spread among members of a household and lead to their deaths. ${ }^{31}$ With the prevention of tuberculosis in mind, the housing survey measured the conditions of homes, including the lighting, ventilation, water, distance from other houses, and the condition of the home's yard. The women who conducted the survey also asked if anyone in the home had been recently sick and for how long that person was ill. The survey took into consideration deaths and sicknesses from tuberculosis from the years 1914 through $1923 .^{32}$

As with the City Club’s earlier garbage and sanitation surveys, the Tuberculosis Housing Survey was indicative of the differences in class between the City Club women and those they surveyed. The women most likely were not surveying the homes in their own neighborhoods, but those homes in the city's poorer neighborhoods. Problems the survey looked for, such as poor ventilation, dirty yards, and bad lighting were not problems that were rampant in middle-class homes. With the belief that tuberculosis could be caused or aggravated by poor housing conditions, the women sought to improve the housing conditions of the poor and thus improve their lives in general. In order to make the correlation between poor housing and tuberculosis, the women must have believed that tuberculosis was most prevalent among the poor. ${ }^{33}$

\footnotetext{
${ }^{31}$ Morel, "Tubercular Children of Kentucky."

32 "Louisville Women's City Club: Housing Survey in Relation to Deaths from Tuberculosis," June 1924, Morel Papers. See the appendix, page vi, for the questions asked in the Housing Survey.

${ }^{33}$ It is possible that Morel saw her family and other middle class families as exceptions. However, it is also possible that Morel's family was not as financially comfortable as the families of other City Club women. Morel held paying jobs throughout her life, as a kindergarten teacher, editor, and in various offices of the City Club. The absence of a marker on the Morel family plot at Cave Hill Cemetery might also indicate the family's lack of funds. The Morels were not as poor as the families living in the neighborhoods Morel and the clubwomen surveyed, but the possibility exists that they were not as wealthy as the families of other City Club women.
} 
The treatment of children with tuberculosis was a special concern of Morel. Together with the City Club, Morel began campaigning for a separate children's unit at one of the existing tuberculosis hospitals in the late 1920s. The women chose Hazelwood State Tuberculosis Hospital as it was the only tuberculosis hospital dedicated to taking patients from across the state, and pushed for a children's wing to be connected with the existing facility. ${ }^{34}$ In 1930 , the clubwomen asked the state to allocate money specifically toward helping children with tuberculosis at Hazelwood; the legislature denied this request most likely because it had agreed to increase its yearly allocation to Hazelwood by $\$ 25,000 .^{35}$ Headed by Morel, who described the current conditions at the hospital as “distressing,” the clubwomen began raising money for the Hazelwood expansion in 1929. City Club members donated money themselves and Morel appealed to clubs across Kentucky. ${ }^{36}$ The women succeeded, as a children's building at Hazelwood was finally completed in 1936 and contained the latest technology in x-rays and plumbing. ${ }^{37}$

Concurrently with their work for a children's unit, Morel and the City Club sought to add more beds to Hazelwood that would accommodate indigent patients from outside Louisville. This continuous effort lasted from the mid-1920s through the early 1930s. Morel urged Kentucky clubs in 1927 to accept a resolution passed by the KFWC the previous year that demanded an additional 250 free beds for tuberculosis patients at the Hazelwood Hospital, where 1100 people were on a waiting list to get into the hospital. The hospital in the late 1920s had only twelve beds reserved for those living

\footnotetext{
${ }^{34}$ Morel, “Tubercular Children of Kentucky”; “Louise Morel to Club President,” 23 March 1931, Morel Papers.

35 "Louise Morel to Clubwomen," 4 March 1930, Morel Papers.

36 "Louise Morel to Clubwomen,” 23 March 1931, Morel Papers; Newspaper clipping, May 1929, Morel Scrapbook.

${ }^{37}$ Morel, “Summary of Accomplishments of Public Health Department under Miss Louise Morel,” c.1938, Morel Papers; The Kentucky Clubwoman, 1937, Morel Papers.
} 
outside Jefferson County. ${ }^{38}$ In her capacity as chair of the KFWC’s Public Health Department, Morel wrote to clubs across the state and asked them to write the governor and their state legislators about the need for more beds at Hazelwood. ${ }^{39}$ The clubwomen themselves helped Hazelwood raise money to acquire more beds through selling Christmas Seals provided by the Kentucky Tuberculosis Association. ${ }^{40}$ Meanwhile, the conditions at Hazelwood continued to deteriorate, which Morel described in detail in an article she wrote for The Kentucky Club Woman magazine, and more people were forced onto the waiting list. Morel and the other clubwomen succeeded in their work when the 1930 Kentucky General Assembly allocated \$25,000 a year for two years to Hazelwood. The new, free beds were included in the children's building the hospital constructed in the mid-1930s. ${ }^{41}$

Morel continued to work for improvements to Hazelwood sanitarium into the 1940s. In 1935, the KFWC chose to honor Morel's tuberculosis work by furnishing a room at Hazelwood in her name. She proposed a resolution to the KFWC Board of Directors in 1941 to make all beds at Hazelwood free to patients. The resolution passed. ${ }^{42}$ Throughout her career, public health remained Morel's primary focus. Interest in health issues was a common theme among municipal housekeepers, especially when it involved helping those afflicted with disease and educating the public on preventing the spread of disease. Morel was specifically interested in both of these goals, as is evident

\footnotetext{
${ }^{38}$ Morel, "Summary of Accomplishments of Public Health Department under Miss Louise Morel”; "Louise Morel to Clubwomen,” 1930, Morel Papers; “Louise Morel to Clubwomen,” 28 February 1927, Morel Papers.

39 "Louise Morel to Club President," 18 January 1927, Morel Papers.

40 "Louise Morel to Clubwomen," 28 November 1930, Morel Papers; Louisville Anti-Tuberculosis Association Papers, 1911-1919, 4 vols., Filson Historical Society, Louisville, KY.

41 "Louise Morel to Clubwomen," 4 March 1930.

42 “State Tuberculosis Hospital Resolution,” 24 September 1941, Morel Papers.
} 
in her work to organize the Health Exposition and improve Louisville's tuberculosis hospitals. 


\section{CHAPTER SIX}

\section{BETTER HOMES IN AMERICA, 1924-1935; THE 1934 HOUSING SURVEY; AND THE CLEANLINESS SURVEY OF 1929-1931}

Municipal housekeepers were concerned with the state of city dwellers' homes, particularly those of the poor, in addition to the city outside of these homes. The homes of the poor had been one of the primary concerns of the Progressive movement. The women of the settlement houses hoped to show, through example, those living around them how to keep their homes. Overcrowded tenement houses became the targets of progressive politicians and activists. Drawing from Progressive ideals about homes, Louise Morel and the City Club women maintained that family homes must be roomy, ventilated, clean, and have as much outdoor yard space as possible. They insisted that dirty and crowded houses led to larger problems such as crime and disease. Municipal housekeepers firmly believed that well-kept homes led to a safer and healthier city. Therefore, in addition to Morel's work to improve the outside community, she also concentrated some effort towards improving the individual homes of Louisville. She maintained that citizens who were proud of their homes would be more likely to participate in improving the city-home. Her work on the Better Homes in America project and the 1934 Housing Survey indicated her desire to improve Louisvillians’ homes. In the Cleanliness Survey of 1929-1931, Morel went one step further and investigated the conditions of public buildings and facilities. 


\section{Better Homes in America, 1924-1935}

Beginning in 1924, Morel served as chair of the Better Homes in America project for several years. Better Homes was a national project that took place yearly in cities throughout the country. Although it had existed for a few years in some cities, the exhibit was first organized nationally in 1922, when it debuted in Louisville. Endorsed by President Warren G. Harding, government and private sector leaders formed the National Advisory Council for Better Homes in America. ${ }^{1}$ The organizers of Better Homes in America described the effects an exhibit of model homes would have on a city in the Better Homes Plan Book of 1922:

[The Better Homes in America project] is a stimulus to better living, civic pride and community morale. It encourages thrift and industry. It develops a higher standard of taste. It means a better community in every way. ${ }^{2}$

Municipal housekeepers involved with Better Homes hoped to promote all of the above in addition to healthy living through well-designed houses.

Women, most of them municipal housekeepers like Morel, organized the Better Homes exhibits in their cities. The National Advisory Council took it for granted that "energetic and capable" women would be the ones encouraging local businesses and community leaders to participate in Better Homes. ${ }^{3}$ For Morel and the City Club, the Better Homes project offered an opportunity to act upon their suggestions for alleviating

\footnotetext{
${ }^{1}$ National Advisory Council for Better Homes in America, Better Homes in America: Plan Book for Demonstration Week, October 9 to 14, 1922 (New York: The Delineator, 1922), 11-12; The CourierJournal, 22 October 1922. Members of the Advisory Council included Vice President Calvin Coolidge, various Cabinet members, the director of the Red Cross, the president of the Chamber of Commerce of the United States, a representative of the Fellow American Institute of Architects, and two women: the president of the General Federation of Women's Clubs and the president of the National Federation of Business and Professional Women's Clubs.

${ }^{2}$ National Advisory Council, Better Homes in America, 12.

${ }^{3}$ Ibid.
} 
disease through better-constructed and well-maintained homes. Through working with Better Homes, Morel showed the community the ideal home—-the first step towards creating the ideal city. ${ }^{4}$

Local architects, builders, furniture businesses, and other businesses volunteered their goods and services to create the houses shown in the Better Homes exhibits. Although the businesses involved were not allowed to advertise their work within or around the homes, they benefited from the exposure. ${ }^{5}$ In Louisville, the project highlighted a few model homes each year in various parts of the city. The houses usually included one or two in white working-class neighborhoods, one built in a predominantly African-American neighborhood (although this was not added until a few years after the exhibit's debut), and a few houses in more upscale parts of town. The showcase's organizers, including Morel, wanted to influence architects, government leaders, and home buyers, and persuade them to build and buy homes that were healthy and comfortable for people to live in.

In 1924, Morel served her first year as the chair of the Louisville Better Homes committee. The committee consisted of women who represented various city districts. The members of the committee coordinated the exhibit homes and encouraged other women in their home districts to visit the exhibits. ${ }^{6}$ That year, the Better Homes houses consisted of two in the Highlands (both on Carolina Avenue) and one, deemed

\footnotetext{
${ }^{4}$ For more information on the "ideal home," see: Chapter Five of Dolores Hayden, Building Suburbia: Green Fields and Urban Growth, 1820-2000 (New York: Pantheon Books, 2003); Dolores Hayden, The Grand Domestic Revolution: A History of Feminist Designs for American Homes, Neighborhoods, and Cities (Cambridge, MA: MIT Press, 1981).

${ }^{5}$ National Advisory Council, Better Homes in America, 12-13; Louise Morel, "Report-Better Homes of America,” 25 May 1924, Louise C. Morel Papers, Kentucky Federation of Women’s Clubs Archives, Louisville, KY. In her "Report," Morel wrote that "there was no sign of commercialism in the houses anywhere...they were purely home-like homes.”

${ }^{6}$ The Louisville Times, 5 May 1924.
} 
affordable, in the Parkway Village neighborhood on Shelby Street. The houses were open to the public for one week in May. ${ }^{7}$ Morel believed the Parkway Village house was especially important because it demonstrated the need for more small homes in the city. Smaller homes, according to Morel, were more healthy and sanitary for people than living in crowded rooming houses or tenements. ${ }^{8}$ The Better Homes organizers added a fourth house in 1925. The homes that year included another in Parkway Village on Shelby Street, one at 800 South 31st Street, and two more in the Highlands at 2504 Glenmary Avenue and the other on Princeton Drive. ${ }^{9}$

Morel used the Better Homes project to vocalize other concerns she held regarding city zoning and services. When speaking about the need for small, affordable housing, Morel noted that zoning and city planning were vital to promoting these homes and eliminating tenement-style housing. She acknowledged that this would not happen overnight, and stated that sewer connections and water service would improve tenements for the short-term. ${ }^{10}$

1926 was the first year the Better Homes exhibit included a house built in a predominantly African-American neighborhood. The city had allocated the blocks on Grand Avenue from $30^{\text {th }}$ Street to $36^{\text {th }}$ Street to redevelopment of housing specifically for African-Americans. Morel supported this plan, as did the rest of the local Better Homes committee. The city found no shortage of businesses willing to rebuild the homes on Grand Avenue. Volunteers included the Best Construction Company, Scott Turner and

\footnotetext{
${ }^{7}$ Courier-Journal, 11 May 1924; Louisville Times, 5 May 1924.

${ }^{8}$ Courier-Journal, May 1924.

${ }^{9}$ Courier-Journal, 26 April 1925.

${ }^{10}$ Courier-Journal, May 1924.
} 
Wittenburg, W.C. Givan and Brown Brothers, and the First Standard Bank. ${ }^{11}$ The Best Construction Company offered to exhibit a home at Grand Avenue and 32nd Street in 1926. The following year, the Better Homes project exhibited another new house on Grand Avenue. The Better Homes exhibit of 1927 also included a house that Morel had designed. The five-room house was located in an upscale neighborhood on Castlewood Avenue near Barrett Avenue. That year's exhibit featured another home in the Highlands that Morel would later buy and live in with two other women. ${ }^{12}$

Morel served as chair of the Louisville Better Homes committee from 1924 through $1935 .^{13}$ She used the project to show others how all citizens could live in a home designed for healthy living. Like the majority of her municipal housekeeping work, the work Morel did on the Better Homes committee was directed toward improving the lives of women and children in Louisville. Most of the organizing and advertising the committee accomplished was led by, and directed toward, the city’s women. As housekeepers, women were the most interested in the state of their homes and doing what they could to improve their homes, thereby improving their families' health and wellbeing. Advertisements spoke of furnishings and decorations in which they believed women would be interested, hoping to draw women to the exhibits. The underlying purpose of the exhibits was to show well-constructed and healthy homes in which Morel believed women would want their families to live.

\footnotetext{
${ }^{11}$ Courier-Journal, 17 June 1926; "Publicity—Better Homes,” c.1926, Morel Papers.

12 "Better Homes in America, May 18-15, 1927" flyer, Louise Morel Scrapbook, Morel Papers; "Louise Morel to Club President,” 14 November 1934, Morel Papers. Morel lived in the house at 2051 Sherwood Avenue from at least 1928 through 1938. See the appendix, page vii, for a picture of the Sherwood Avenue house.

13 “Louise Morel to ?,” 18 May 1929, Morel Papers.
} 
Morel and the committee also worked with local schoolchildren, starting a model house contest for children of all ages to enter. In 1928, children from thirty-eight schools entered the contest. Contestants built miniature model homes, keeping in mind the necessities for a healthy home. ${ }^{14}$ Through constructing model homes similar to the actual homes being built, children learned what qualities made a well-constructed and safe home.

\section{The 1934 Housing Survey}

Morel's interest in improved housing did not end with the Better Homes exhibits. Concurrently, she conducted a survey that supported her claims that bad housing led to an unhealthy and unsafe neighborhood. Morel’s 1924 Tuberculosis Housing Survey directly influenced her 1934 survey. She conducted the 1924 survey to establish possible causes or aggravations to tuberculosis found in homes. Besides encouraging the rest of Morel's work against tuberculosis, the 1924 survey also led her to work for improved housing. 1924 was the first year she was chair of the Better Homes project. Ten years later, Morel conducted a second housing survey. This second survey went into more detail on housing problems and solutions than did the first survey because it looked for all possible problems, not just those that might have caused tuberculosis.

Morel conducted the Housing Survey in conjunction with the Louisville City Planning and Zoning Commission's Slum Clearance project. ${ }^{15}$ Morel often referred to the survey as the Slum Clearance Survey. Unlike her earlier surveys on garbage separation or housing, the City Club women gathered all of the statistics from police

\footnotetext{
14 "Rules for Model Home Contest," c.1929, Morel Papers; “Louise Morel to Clubwomen,” 5 June 1929, Morel Papers. The contest rules specified the size of the models and their correlation to actual house sizes, the sizes of windows and doors, and ideal sizes for yards.

15 “Louisville Women’s City Club Bulletin,” 1934, Morel Scrapbook.
} 
records and hospital files, and did not go door to door. ${ }^{16}$ Within these records, Morel and the clubwomen searched for reports on thirteen different occurrences:

- Major and Minor Crimes. These statistics came from cases reported in 1933.

- $\quad$ Municipal Relief Bureau Cases in 1933.

- Tuberculosis Cases and Deaths in 1933.

- $\quad$ City Hospital Cases in 1933.

- Delinquent and Dependent Children in 1933.

- Diphtheria Cases and Deaths 1925, 1930, and 1933.

- Whooping Cough Cases and Deaths in 1925, 1930, and 1933.

- $\quad$ Public Health Nursing Cases in 1933.

- Infant Mortality Rates in 1925, 1930, and 1933.

- $\quad$ Insane and Narcotic Cases in 1933.

- $\quad$ Family Service Cases in 1933.

- $\quad$ Measles Cases and Deaths in 1925, 1930, and 1933.

- $\quad$ Scarlet Fever Cases and Deaths in 1925, 1930, and 1933. ${ }^{17}$

After gathering the locations and numbers of each type of problem, Morel made several maps of the city. Each problem received its own map. For instance, she created a map that showed every case and location of whooping cough in the city. She also compiled all instances and locations of the thirteen problems into one map. While the individual

\footnotetext{
16 "KFWC Clubwoman,” 1938, Morel Scrapbook.

17 “CWA Housing Survey,” 1934, Morel Papers.
} 
maps helped pinpoint where certain problems existed, the compilation map was intended to highlight the city’s blighted areas. The entire project took several months. ${ }^{18}$

Upon finishing the survey, Morel named four districts, located in the central downtown area of the city, slums. ${ }^{19}$ This information was intended to aid the city zoning department in its efforts to eradicate slum areas through redevelopment. However, the city needed a large sum of money in order to begin the redevelopment project. Morel sent her findings to the Public Works Administration (PWA) in Washington, DC and asked the agency to allocate three million dollars to Louisville redevelopment. The PWA responded with one and a half million dollars, which the city dedicated toward razing existing housing in the so-called slum areas and replacing this housing with new, inexpensive homes in a "park-like setting."20 These homes were to serve as models for new low-cost housing throughout the city. ${ }^{21}$

As with the Tuberculosis Housing Survey in 1924 and the 1920 Sanitary Survey, the 1934 Housing Survey delineated class differences between the clubwomen and those they surveyed. The so-called blighted neighborhoods were not those in which the clubwomen lived. Through razing the homes in areas with high crime rates and then rebuilding new neighborhoods, Morel and the clubwomen hoped to improve the lives of the poor by giving them homes more like those of the middle class. Better houses, to the clubwomen, equaled less crime, less disease, and people with values more like themselves.

\footnotetext{
18 “KFWC Clubwoman,” 1938; Courier-Journal, 6 April 1934. See the appendix, page viii, for one of this survey's maps.

${ }^{19}$ Courier-Journal, 6 April 1934. One of the four districts was an African-American neighborhood; the others were white neighborhoods.

${ }^{20}$ Ibid.

${ }^{21}$ Ibid.
} 
With the Better Homes in America exhibits and the Housing Survey in 1934, Morel concentrated on the condition of individual families' homes. Individual homes were of primary concern to municipal housekeepers because it was within their homes that women raised their families to become productive members of the community. If the city's housekeepers insisted on clean, roomy homes for their families, they would be more apt to demand a clean and well-kept city. However, municipal housekeepers were true to their name; they were also interested in maintaining healthy conditions within the larger community home.

\section{The Cleanliness Survey, 1929-1931}

While she worked on the Better Homes project, Morel conducted another survey over the course of three years. The Cleanliness Survey evaluated the conditions of public buildings around the city. In a summary of the survey, Morel noted that similar campaigns had been conducted in other cities, but that they had only considered the exteriors of public buildings. Morel's survey concentrated on the conditions of the interiors of city buildings, and particularly those areas in which individuals encountered germs, such as restrooms, drinking fountains, and bathing areas. ${ }^{22}$

Morel began the survey with the aid of both the Kentucky and Louisville health departments and the cooperation of the mayor. She worked with over sixty local voluntary organizations to finish the survey. ${ }^{23}$ Morel split the survey into broad categories: white elementary schools, white junior and high schools, African-American schools of all levels, theaters, libraries, parks and playgrounds, factories, hospitals, public swimming pools, public buildings such as the courthouse, jail, post office branches,

\footnotetext{
${ }^{22}$ Louise Morel, “A City Checks Up: Louisville learns how far Citizens Practice Cleanilness [sic] in Public Places,” c.1932, Morel Papers, 1.

${ }^{23}$ Ibid.
} 
railroad stations, and streetcars, laundromats, meat packers, and many other buildings frequented by the public. The volunteers who visited the buildings had a list of items to investigate depending upon what type of building or facility they conducted the survey. For most places, they counted the numbers of drinking fountains and sinks. They found out how many cleaning buckets the facility had and how many cakes of soap were used per year. These numbers were compared to the number of daily or yearly visitors to the building. For swimming pools they recorded the water temperature and asked how often the facility cleaned the showers. ${ }^{24}$

When all the statistics were gathered, Morel handed them over to the Kentucky health department where others tabulated the statistics into readable tables. ${ }^{25}$ The tables proved useful later when Morel and her colleagues sought to rectify unhealthy conditions in the surveyed facilities. As the volunteers conducted the survey, they often pointed out unsanitary conditions or other problems to the heads or managers of the facilities they examined. In cases such as this, the people or facilities fixed the problems on their own without any other intervention by Morel or other survey volunteers. Other conditions required different methods of action. They reported violations of city ordinances to the appropriate city agency. If no ordinance existed, they began work to introduce one. ${ }^{26}$

The Cleanliness Survey, like several of Morel's other surveys, is an example of middle class women striving to "improve" the lives of the poorer class. At some of the city's high schools, the women found girls who, in their opinion, "needed instruction in cleanliness and good grooming.” Although the survey did not take into consideration the

\footnotetext{
${ }^{24}$ Cleanliness Survey tables, c.1931, Morel Papers.

${ }^{25}$ Ibid. The Kentucky Federation of Women's Clubs has all of the tables from the Cleanliness survey in their archives at KFWC headquarters in Louisville. This survey is the only one of Morel's surveys with the complete final product in the archives.

${ }^{26}$ Louisville Herald-Post, 1 October 1932.
} 
people using the public facilities, these girls received a booklet published by the Cleanliness Institute in New York entitled “The 30-Day Loveliness Test.” 27 The clubwomen believed that improving buildings, and in this example, personal appearance, would lead to the improvement of an entire class of people and the city as a whole.

After she completed the survey in Louisville, Morel encouraged clubwomen throughout Kentucky to conduct a similar survey in their communities. She sent interested clubs a detailed guide to covering all public buildings and facilities in their city or town. The guide included ideas on facilities to visit and items to investigate in those facilities. ${ }^{28}$ The Cleanliness Survey is another example of Morel's work as a municipal housekeeper. In one description of the survey, Morel stated, "We wanted to take good housekeeping, as we know it in our own homes, and extend it all through the city."29 Morel acknowledged that the survey was not a cure-all for health problems in Louisville, but she believed that education of the public on sanitary matters was a first step. ${ }^{30}$

\footnotetext{
${ }^{27}$ Ibid.

${ }^{28}$ Louise Morel, “A Challenge to Your Community in Cleanliness and Sanitation: Find the Facts,” c.1932, Morel Papers.

${ }^{29}$ Louise Morel, “Louisville’s Three Year Cleanliness Campaign,” 1932, Morel Papers.

${ }^{30}$ Louisville Herald-Post, 1 October 1932.
} 


\section{CHAPTER SEVEN}

\section{CONCLUSION}

The Louisville Women’s City Club was a vital organization during the 1920s and 1930s. During World War II and in the years that followed, the club remained concerned with city problems, but also began to change in the way that most women's clubs changed during the 1950s. A scan of newspaper headlines about the City Club during the late 1940s through the 1960s shows only a smattering of reform-related articles. ${ }^{1}$ Most articles speak of the club’s choir, its yearly flower show, and other, more social, events. This indicates two possibilities. The first is that the City Club followed a trend that affected most other women's clubs in the mid-twentieth century when social activities began to prevail over reform activities. The other possibility is that the newspapers only covered the club’s social activities. A lack of records from this era of the Louisville Women's City Club leaves this question open. Most likely it was a combination of these two possibilities. As the club’s reforming women grew older, retired, and passed away, the reform tradition became less central to the club’s activities. As a result, newspapers covered social events more often than the club’s reform activities. ${ }^{2}$ The Louisville Women’s City Club was active until at least the mid-1980s. Shortly after the club’s

\footnotetext{
${ }^{1}$ The Courier-Journal, various articles, 1944-1963.

${ }^{2}$ Janice Theriot discussed this trend as it related to the Kentucky Federation of Women's Clubs in Tradition of Service: A History of the Kentucky Federation of Women's Clubs (Louisville, KY: Kentucky Federation of Women's Clubs, 1994). Interestingly, the 1950s and early 1960s were when the clubs boasted their highest membership numbers.
} 
demise, the president donated the club’s records (most of which are from the 1910s and 1920s) to the Filson Historical Society in Louisville. ${ }^{3}$

This is not an exhaustive look at Louise Morel's, or the City Club’s, reform work. Throughout her records, Morel mentioned several other activities in which she and the club were involved, including the prevention of venereal diseases, treatment of cancer, city zoning and planning, schools’ involvement in children's health, and her work as an officer in the General Federation of Women's Clubs. These activities are not included here for consideration of space, time, and fluidity, and also because of a general lack of records regarding these fields of work. These are all possible areas of future research, as is an investigation into the City Club after Louise Morel's involvement.

Morel's work is an example of the work that appealed to women interested in reform in cities across the United States, both before and after 1917. Rapidly growing cities faced problems with efficient garbage collection, the spread of disease especially among children, low-quality housing, crowded public buildings, and sewer capacity. These problems were the ones in which women such as Morel took an interest because of the immediate impact these issues had on everyday life in the city. Morel became known as a municipal housekeeper because addressing problems such as garbage collection and poor housing required a literal cleaning-up of the city.

Municipal housekeeping was a reform movement that existed in cities during the Progressive Era and in the years after 1917. Women interested in reform often became interested through municipal housekeeping work because the problems it addressed in the city were similar to the daily work they did at home. Municipal housekeeping, because of its nature, also provided an acceptable means for women to involve themselves in

\footnotetext{
${ }^{3}$ Louisville Women’s City Club Papers, uncatalogued, Filson Historical Society, Louisville, KY.
} 
work outside of the home. Morel is an excellent example of a municipal housekeeper during the 1920s and 1930s because although her work was traditional municipal housekeeping work, she used at least one method that was not available to earlier municipal housekeepers: appealing to women voters. When working for increased sewer capacity and expanded tuberculosis hospitals, Morel and the City Club women campaigned for bonds to pay for the improvements, and they directed a large part of their efforts toward women voters.

Addressing their efforts to women who voted was not the only method available to Morel and the City Club women. They also relied upon methods that had worked for reformers for years: they took surveys, held conventions, gave speeches to interested groups, wrote letters, and worked with city officials. Their goal was not only to find solutions to city problems through using methods such as surveys, but also to educate the public. The City Club often presented their work to the city or displayed it for the public to see. In addition, Morel frequently spoke to city schoolchildren. Although the City Club confined its work to Louisville, Morel supplied women’s clubs in other towns and cities with instructions and examples so they could conduct surveys and work with their own city governments to address local problems.

Most of the people the City Club, a white middle class organization, sought to help were financially less well-off than City Club members. When taking surveys or addressing city problems, the club did not concentrate most of their efforts on their own neighborhoods, but focused instead on the city's poorer neighborhoods. When tackling such issues as garbage separation, the women did so from their own perspective. They saw cleaner city streets as worth the time and money it took to separate garbage into 
containers. Some people Morel surveyed could not afford the cans that garbage separation required or had more pressing problems they wanted the city to address. ${ }^{4}$ It is also likely that the women surveyed did not have the time to separate garbage if they had to work and care for their family and their home. One also wonders how these women felt when middle-class women, who apparently did not have to work if they had to time to knock on doors and inquire about household garbage, came to check on how well they kept their homes. Morel and the City Club women, like others involved in reform work, wanted to improve their cities through "improving" the poor and working classes of the cities.

Although the City Club was a white women's organization, it occasionally addressed the needs of African-American families as they paralleled the needs of white families. For example, the Better Homes exhibits included a home in a primarily black neighborhood. Also, when surveying public buildings and parks, Morel included the buildings and areas designated for African-Americans. Although the City Club acknowledged that African-Americans in Louisville faced some of the same problems as white families, such as finding affordable housing of a good quality and the need for safe and clean buildings, the City Club never addressed needs that were primarily AfricanAmerican. Morel and the City Club did not consider discrimination, everyday safety issues, available education, or other problems that African-Americans faced alone. It would be interesting to find out whether there was a woman or a club, like Louise Morel and the City Club, who worked for reforms that would benefit Louisville's AfricanAmerican community.

\footnotetext{
4 “Point: Garbage,” 1918, Louise C. Morel Papers, Kentucky Federation of Women’s Clubs Archives, Louisville, KY.
} 
Louise Morel’s work with the Louisville Women’s City Club shows the continuation of Progressive ideals into the 1920s and 1930s. The Progressive movement did not end completely with the beginning of World War I or the success of women's suffrage. Women such as Morel succeeded in promoting reforms to improve their cities after the so-called end of the Progressive Era. Morel's concerns with garbage collection, public health, and the safety of homes and public buildings were the same concerns earlier municipal housekeepers. Although it was no longer their only option, municipal housekeeping continued to give women an opportunity to work outside their homes to improve the lives of city dwellers. 


\section{REFERENCES}

\section{Primary Sources}

Addams, Jane. The Second Twenty Years at Hull House. New York: The Macmillan Co., 1930.

---. Twenty Years at Hull House. New York: The Macmillan Co., 1911.

Administration Files. Kentucky Federation of Women's Clubs Archives, Louisville, KY.

Allison Family Papers, 1891-1965. Filson Historical Society, Louisville, KY.

Allison, Young Ewing Papers, 1878-1943. Filson Historical Society, Louisville, KY.

Bernheim, Isaac Wolfe. The Story of the Bernheim Family. Louisville, KY: J.P. Morton and Company, 1910.

Bowen, Louise de Koven. Growing Up With a City. New York: The Macmillan Co., 1926.

Brandeis Collection, 1881-1939. University of Louisville Archives, Louisville, KY.

Caron’s Louisville City Directory. Filson Historical Society, Louisville, KY.

Cave Hill Cemetery Record. Filson Historical Society, Louisville, KY.

Civic Journal, Louisville, KY.

The Club Woman. Kentucky Federation of Women's Clubs Archives, Louisville, KY.

Compilation of General Ordinances of the City of Louisville. Louisville: The Standard Printing Co., Inc., c.1920.

Compilation of General Ordinances of the City of Louisville (Through December 31, 1923). Louisville: n.p., 1923.

The Courier-Journal, Louisville, KY. 
Ely, Mary L. and Eve Chappell. Women in Two Worlds. New York: American Association for Adult Education, 1938.

Johnson City Press-Chronicle, Johnson City, TN.

Kentucky Advocate, Danville, KY.

Kentucky Federation of Women's Clubs Yearbooks. Kentucky Federation of Women's Clubs Archives, Louisville, KY.

Lexington Herald, Lexington, KY.

Louisville Anti-Tuberculosis Association Papers, 1911-1919. 4 vols. Filson Historical Society, Louisville, KY.

Louisville Death Records. Microfilm Collection. Filson Historical Society, Louisville, KY.

Louisville Herald, Louisville, KY.

Louisville Herald-Post, Louisville, KY.

The Louisville Times, Louisville, KY.

Louisville Women’s City Club Papers (uncatalogued). Filson Historical Society, Louisville, KY.

Morel, Louise C. Papers. Kentucky Federation of Women’s Clubs Archives, Louisville, KY.

National Advisory Council for Better Homes in America. Better Homes in America: Plan Book for Demonstration Week, October 9 to 14, 1922. New York: The Delineator, 1922.

The New Highlander, Louisville, KY.

Simkhovitch, Mary Kingsbury. Neighborhood: My Story of Greenwich House. New York: Norton, 1938.

Speed Family Papers, 1751-1921. Filson Historical Society, Louisville, KY.

Speed Family Papers, 1816-1961. University of Louisville Archives, Louisville, KY.

Speed, James Miscellaneous Papers, 1840-1873. Filson Historical Society, Louisville, KY. 
Speed Miscellaneous Papers, 1797-1977. Filson Historical Society, Louisville, KY.

Speed, Thomas, comp. Records and Memorials of the Speed Family. Louisville, KY: Courier-Journal Job Printing Company, 1892.

Speed, Thomas Letter Book, 1863-1896. Filson Historical Society, Louisville, KY.

Speed, Thomas Scrapbook. Filson Historical Society, Louisville, KY.

Supplement to Eleventh Biennial Compilation of General Ordinances of the City of Louisville, Including Amendments to City Charter Passed by Legislature, 191718. Louisville: George G. Fetter Co., 1918.

Taylor, Graham. Chicago Commons Through Forty Years. Chicago: Chicago Commons Association, 1936.

United States Census, 1880. Microfilm Collection. Filson Historical Society, Louisville, $\mathrm{KY}$.

Wald, Lillian D. The House on Henry Street. New York: H. Holt and Co., 1915.

Willard, Frances. Woman and Temperance: Or, The Work and Workers of the Woman's Christian Temperance Union. Hartford: Park Publishing Co., 1883.

Woman's Club of Louisville History. Vol. 1. Filson Historical Society, Louisville, KY.

Woman’s Club of Louisville Yearbooks, 1921 and 1927. Filson Historical Society, Louisville, KY.

Wood, Mary I. The History of the General Federation of Women's Clubs for the First Twenty-Two Years of its Organization. New York: The General Federation of Women’s Clubs, 1912.

\section{Secondary Works}

\section{Books}

Addams, Jane. My Friend, Julia Lathrop. New York: Macmillan, 1935.

Blair, Karen. The Clubwoman as Feminist: True Womanhood Redefined. New York: Holmes and Meier Publishers, 1980. 
Blocker, Jack S., Jr. American Temperance Movements: Cycles of Reform. Boston: Twayne Publishers, 1989.

Blumberg, Dorothy R. Florence Kelley: The Making of a Social Pioneer. New York: A.M. Kelley, 1966.

Bordin, Ruth. Frances Willard: A Biography. Chapel Hill and London: University of North Carolina Press, 1986.

---. Woman and Temperance: The Quest for Power and Liberty. Philadelphia: Temple University Press, 1981.

Bowling, Patricia Kurtz. Reuben Post Halleck: A Biography. MA Thesis, University of Louisville, 1968.

Breckinridge, Sophonisba Preston. Madeline McDowell Breckinridge: A Leader in the New South. Chicago: University of Chicago Press, 1921.

Campbell, Barbara K. The "Liberated" Woman of 1914: Prominent Women in the Progressive Era. N.c.: UMI Research Press, 1979.

Carson, Mina. Settlement Folk: Social Thought and the American Settlement Movement, 1885-1930. Chicago: University of Chicago Press, 1990.

Cash, Floris Barnett. African-American Women and Social Action: The Clubwomen and Volunteerism from Jim Crow to the New Deal, 1896-1936. Westport, CT: Greenwood Press, 2001.

Chambers, Clarke. Seedtime of Reform: American Social Service and Social Action, 1918-1933. Minneapolis: University of Minnesota Press, 1963.

Clark, Ida Clyde Gallagher. American Women and the World War. New York: D. Appleton and Co., 1918.

Costin, Lela B. Two Sisters for Social Justice: A Biography of Grace and Edith Abbott. Urbana, IL: University of Illinois Press, 1983.

Crocker, Ruth Hutchinson. Social Work and Social Order: The Settlement Movement in Two Industrial Cities, 1889-1930. Urbana, IL: University of Illinois Press, 1992.

Davis, Allen F. Spearheads for Reform: The Social Settlements and the Progressive Movement, 1890-1914. New York: Oxford University Press, 1967.

Dillman, Grace M. Emma J. Woerner, Louisville Educator. MA Thesis, University of Louisville, 1951. 
Duffy, John. The Sanitarians: A History of American Public Health. Urbana, IL: University of Illinois Press, 1990.

Epstein, Barbara Leslie. The Politics of Domesticity: Women, Evangelism, and Temperance in Nineteenth-Century America. Middletown, CT: Wesleyan University Press, 1981.

Ginzberg, Lori. Women and the Work of Benevolence: Morality, Politics, and Class in the Nineteenth-Century United States. New Haven: Yale University Press, 1990.

Goldmark, Josephine C. Impatient Crusader: Florence Kelley’s Life Story. Urbana, IL: University of Illinois Press, 1953.

Gordon, Linda. Pitied but Not Entitled: Single Mothers and the History of Welfare, 1890-1935. New York: Free Press, 1994.

Haines, Anna J. Tuberculosis in Louisville and Jefferson County. MA Thesis, University of Louisville, 1943.

Hayden, Dolores. Building Suburbia: Green Fields and Urban Growth, 1820-2000. New York: Pantheon, 2003.

---. The Grand Domestic Revolution: A History of Feminist Designs for American Homes, Neighborhoods, and Cities. Cambridge, MA: MIT Press, 1981.

Hill, Caroline Miles. Mary McDowell and Municipal Housekeeping: A Symposium. Chicago: Lithographed by Millar Publishing Co., 1938.

Karger, Howard Jacob. The Sentinels of Order: A Study of Social Control and the Minneapolis Settlement House Movement, 1915-1950. Lanham, MD: University Press of America, Inc., 1987.

Kleber, John, ed. The Encyclopedia of Louisville. Lexington, KY: The University Press of Kentucky, 2001.

Knupfer, Anne Meis. Toward a Tenderer Humanity and a Nobler Womanhood: AfricanAmerican Women's Clubs in Turn-of-the-Century Chicago. New York: New York University Press, 1996.

Lasch-Quinn, Elisabeth. Black Neighbors: Race and the Limits of Reform in the American Settlement House Movement, 1890-1945. Chapel Hill, NC: The University of North Carolina Press, 1993.

Martin, Theodora Penny. The Sound of Our Own Voices: Women's Study Clubs 18601910. Boston: Beacon Press, 1987. 
Munrolo, Priscilla. The Common Ground of Womanhood: Class, Gender, and Working Girls’ Clubs, 1884-1928. Urbana, IL: University of Illinois Press, 1997.

Neverdon-Morton, Cynthia. Afro-American Women of the South and the Advancement of the South and the Advancement of the Race, 1895-1925. Knoxville, TN: University of Tennessee Press, 1989.

Rosen, Ruth. The Lost Sisterhood: Prostitution in America, 1900-1918. Baltimore: The Johns Hopkins University Press, 1982.

Rosenberg, Rosalind. Divided Lives: American Women in the Twentieth Century. New York: Hill and Wang, 1992.

Rothman, Sheila. Woman's Proper Place: A History of Changing Ideals and Practices, 1870 to the Present. New York: Basic Books, Inc., Publishers, 1978.

Rouse, Jacqueline A. Lugenia Burns Hope: Black Southern Reformer. Athens, GA: The University of Georgia Press, 1989.

Schechter, Patricia A. Ida B. Wells-Barnett and American Reform, 1880-1930. Chapel Hill, NC: University of North Carolina Press, 2001.

Sklar, Kathryn Kish. Women's Rights Emerges Within the Anti-Slavery Movement, 18301870: A Brief History with Documents. Boston and New York: Bedford/St. Martin's, 2000.

Theisen, Norma E. A Study of the Origin and Development of the Theodore Ahrens Trade School. MA Thesis, University of Louisville, 1942.

Theriot, Janice. Tradition of Service: A History of the Kentucky Federation of Women's Clubs, 1894-1994. Louisville, KY: Kentucky Federation of Women’s Clubs, 1994.

Tomes, Nancy. The Gospel of Germs: Men, Women, and the Microbe in American Life. Cambridge, MA: Harvard Univeristy Press, 1998.

Wells, Mildred White. Unity in Diversity: The History of the General Federation of Women's Clubs. Washington, DC: General Federation of Women's Clubs, 1953.

Wilson, Howard Eugene. Mary McDowell, Neighbor. Chicago: University of Chicago Press, 1928.

Works Projects Administration Service Division, comp. Libraries and Lotteries: A History of the Louisville Free Public Library. Cynthiana, KY: Hobson Book Press, 1944. 
Zaeske, Susan. Signatures of Citizenship: Petitioning, Antislavery, and Women's Political Identity. Chapel Hill, NC: University of North Carolina Press, 2003.

\section{Articles}

Boris, Eileen. "Reconstructing the 'Family': Women, Progressive Reform, and the Problem of Social Control.” In Gender, Class, Race, and Reform in the Progressive Era. Edited by Noralee Frankel and Nancy S. Dye, 73-86. Lexington, KY: The University Press of Kentucky, 1991.

Brandeis, Adele. “Oral History Interview with Adele Brandeis.” 1 June 1965. Interviewed by Harlan Phillips. Smithsonian Archives of American Art. http://artarchives.si.edu/oralhist/brande65.htm.

Conway, Jill. “Women Reformers and American Culture, 1870-1930.” Journal of Social History 5 (1971-1972): 164-177.

Flanagan, Maureen A. “Gender and Urban Reform: The City Club and the Woman's City Club of Chicago in the Progressive Era." The American Historical Review 95 (October 1990): 1032-1050.

Gordon, Linda. "Black and White Visions of Welfare: Women's Welfare Activism, 1890-1945.” The Journal of American History 78 (Sept. 1991): 559-590.

Gordon, Michael, "The Social Survey Movement and Sociology in the United States," Social Problems 21 (Fall 1973): 284-298.

Hewitt, Nancy A. "Politicizing Domesticity: Anglo, Black, and Latin Women in Tampa's Progressive Movements.” In Gender, Class, Race, and Reform in the Progressive Era. Edited by Noralee Frankel and Nancy S. Dye, 24-41. Lexington, KY: The University Press of Kentucky, 1991.

Hine, Darlene Clark. "We Specialize in the Wholly Impossible: The Philanthropic Work of Black Women.” In Lady Bountiful Revisited: Women, Philanthropy, and Power. Edited by Kathleen D. McCarthy, 70-88. New Brunswick, NJ: Rutgers University Press, 1990.

Jones, Beverly W. "Mary Church Terrell and the National Association of Colored Women, 1896-1901.” The Journal of Negro History 67 (Spring 1982): 20-33.

Karger, Howard Jacob. "Phyllis Wheatley House: A History of the Minneapolis Black Settlement House, 1924-1940.” Phylon 47 (1986): 79-90.

Kerber, Linda K. "Separate Spheres, Female Worlds, Woman's Place: The Rhetoric of Women’s History.” The Journal of American History 75 (June 1988): 9-39. 
Ladd-Taylor, Molly. "Hull House Goes to Washington: Women and the Children's Bureau.” In Gender, Class, Race, and Reform in the Progressive Era. Edited by Noralee Frankel and Nancy S. Dye, 110-126. Lexington, KY: The University Press of Kentucky, 1991.

Lebsock, Suzanne. “Across the Great Divide: Women and Politics, 1890-1920.” In Women, Politics, and Change. Edited by Louise Tilly and Patricia Gurin, 35-62. New York: Russell Sage Foundation, 1990.

“The Point.” In The Encyclopedia of Louisville. Edited by John Kleber, 710-711. Lexington, KY: The University Press of Kentucky, 2001.

Scott, Anne Firor. “As Easily as They Breathe...” In Making the Invisible Woman Visible. Edited by Anne Firor Scott. Urbana, IL: University of Illinois Press, 1984.

---. “Most Invisible of All: Black Women’s Voluntary Associations.” The Journal of Southern History 56 (Feb. 1990): 3-22.

---. "Women's Voluntary Associations in the Forming of American Society." In Making the Invisible Woman Visible. Edited by Anne Firor Scott. Urbana, IL: University of Illinois Press, 1984.

Shaw, Stephanie J. "Black Club Women and the Creation of the National Association of Colored Women.” The Journal of Women's History 3 (Fall 1991): 10-25.

Sicherman, Barbara. "Working it Out: Gender, Profession, and Reform in the Career of Alice Hamilton.” In Gender, Class, Race, and Reform in the Progressive Era. Edited by Noralee Frankel and Nancy S. Dye, 127-147. Lexington, KY: The University Press of Kentucky, 1991.

Terborg-Penn, Rosalyn. “African-American Women’s Networks in the Anti-Lynching Crusade.” In Gender, Class, Race, and Reform in the Progressive Era. Edited by Noralee Frankel and Nancy S. Dye, 148-161. Lexington, KY: The University Press of Kentucky, 1991.

Welter, Barbara, “The Cult of True Womanhood, 1820-1860,” American Quarterly 18 (Summer 1966): 151-174.

White, Deborah Gray. “The Cost of Club Work, The Price of Black Feminism.” In Visible Women: New Essays on American Activism. Edited by Nancy Hewitt and Suzanne Lebsock, 247-269. Urbana, IL: University of Illinois Press, 1993.

Wortman, Marlene Stein. "Domesticating the Nineteenth-Century American City." Prospects: An Annual of American Cultural Studies 3 (1977): 531-572. 


\section{Other}

Metropolitan Sewer District (MSD) History, Louisville, KY, http://www.msdlouky.org/aboutmsd/history.htm.

National Council of Jewish Women (NCJW) —Louisville Section, updated 12 August 2003, http://www.ncjwlou.org. 
APPENDIX I

\section{PHOTOGRAPHS AND DOCUMENTS}




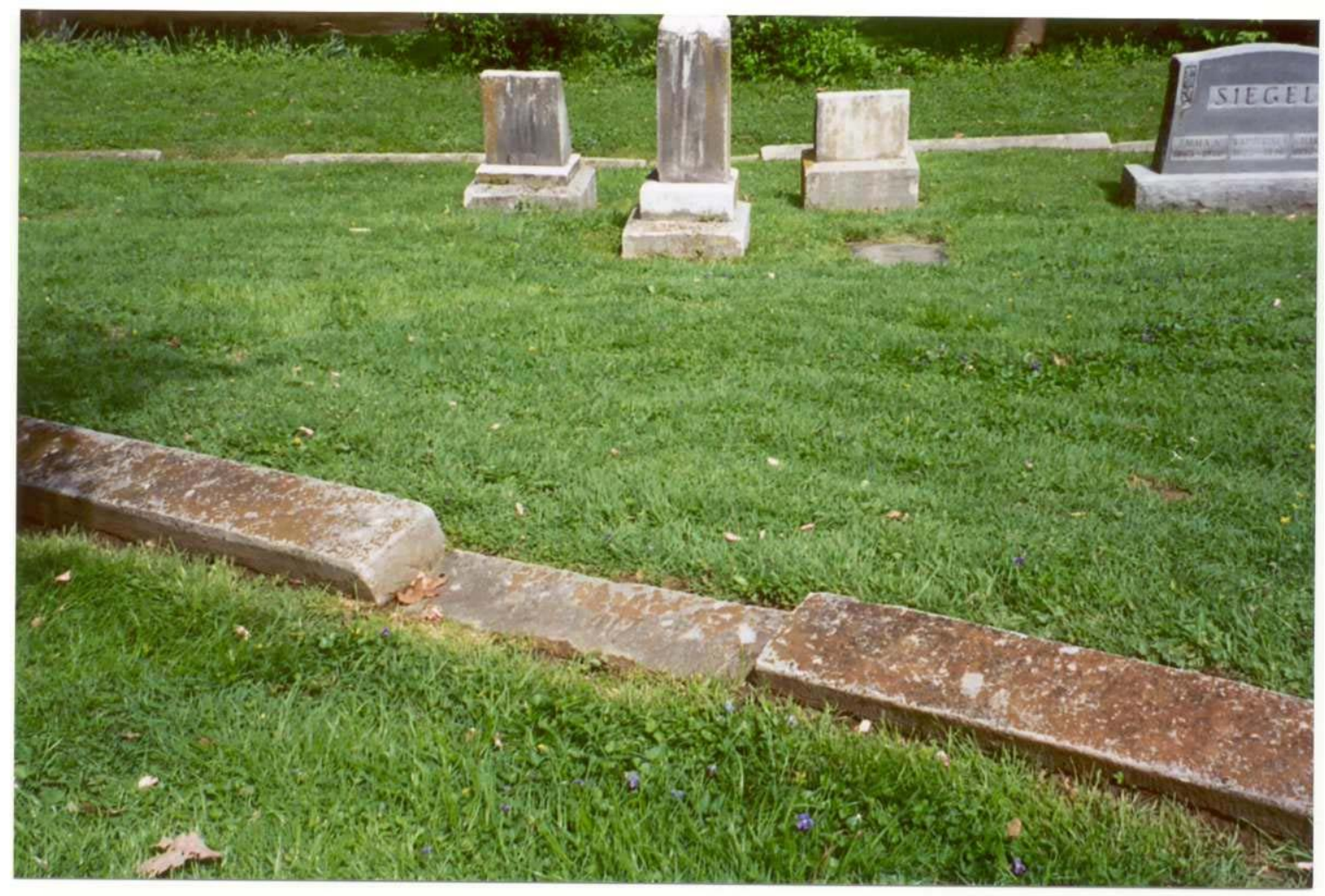

Morel Family Plot (Unmarked)—Cave Hill Cemetery

2004 

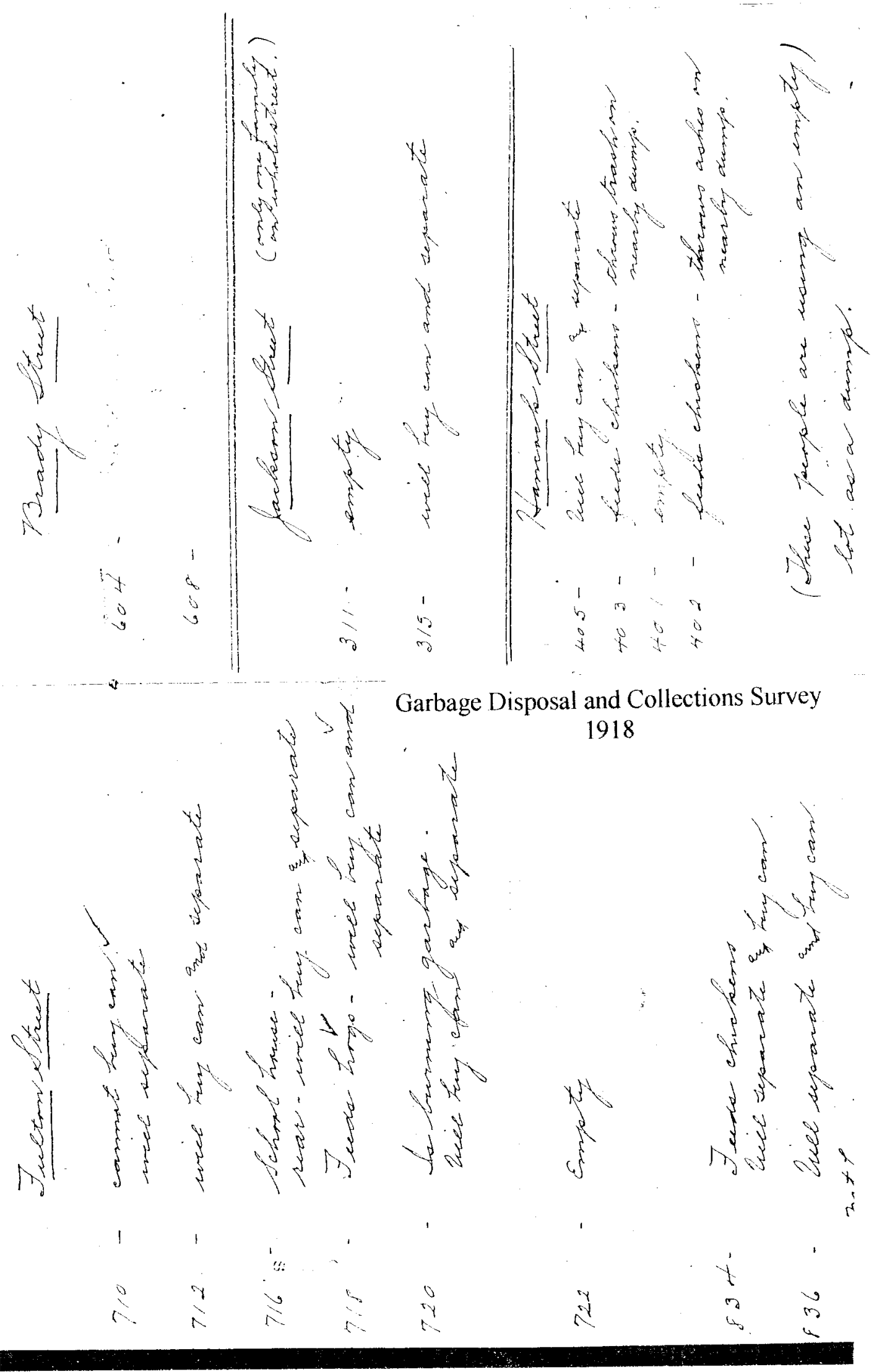


\section{THE PLEDGE.}

I promise to assist in the City Betterment Movement. I will help keep Louisville a clean and beautiful city-in the following ways,

1. I will keep my premises clean and co-operate with my neighbors in keeping the street in front and the alley in the rear free from paper, rubbish and glass.

2. I will not throw rinds, or peel of oranges, lemons, apples or other fruit on the sidewalk or in the street.

3. I will aid in preventing fires by keeping my house, from attic to cellar, free from rubbish, rags and waste paper, and by being careful in the use of matches and other explosives.

4. I will save all papers, rags and metal to be salvaged.

5. I will place a covered can or box for any rubbish.

6. I will use a covered garbage can and keep all food refuse free from anything hurtful to hogs.

7. I will keep all manure in covered receptacles or screened bin and have same promptly removed.

8. I will not use vacant lots as a dumping ground.

9. I will aid in any way I can to exterminate the house fly.

10. I will cut weeds on my property.

11. I will improve my premises by planting.

12. I will observe the city ordinances relative to sanitation, garbage, removal of manure, dirty premises, streets and alleys, proper sewer connections, open vaults, pumps, bad housing and other matters pertaining to public health. I will report any neglect of ordinances to the 


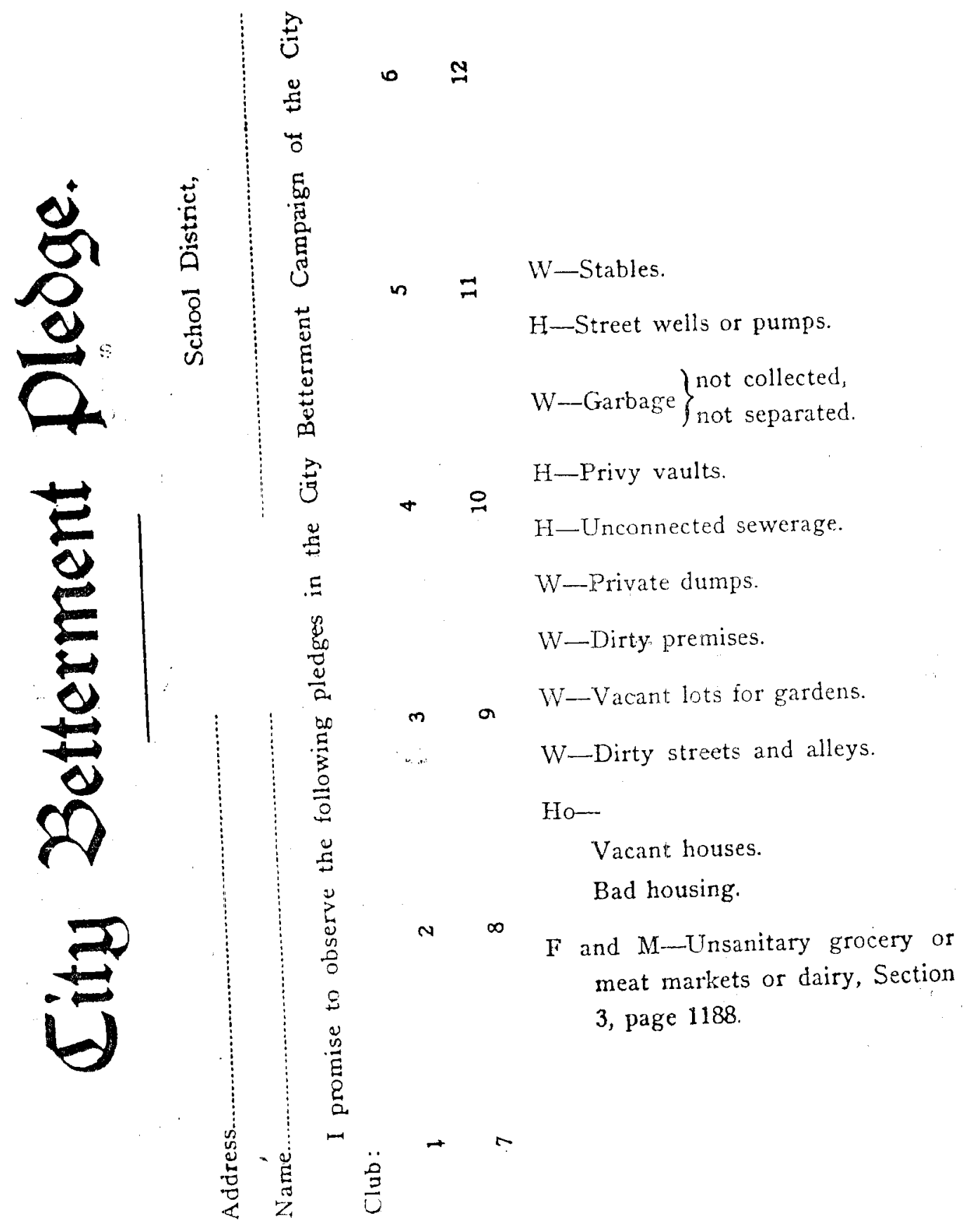




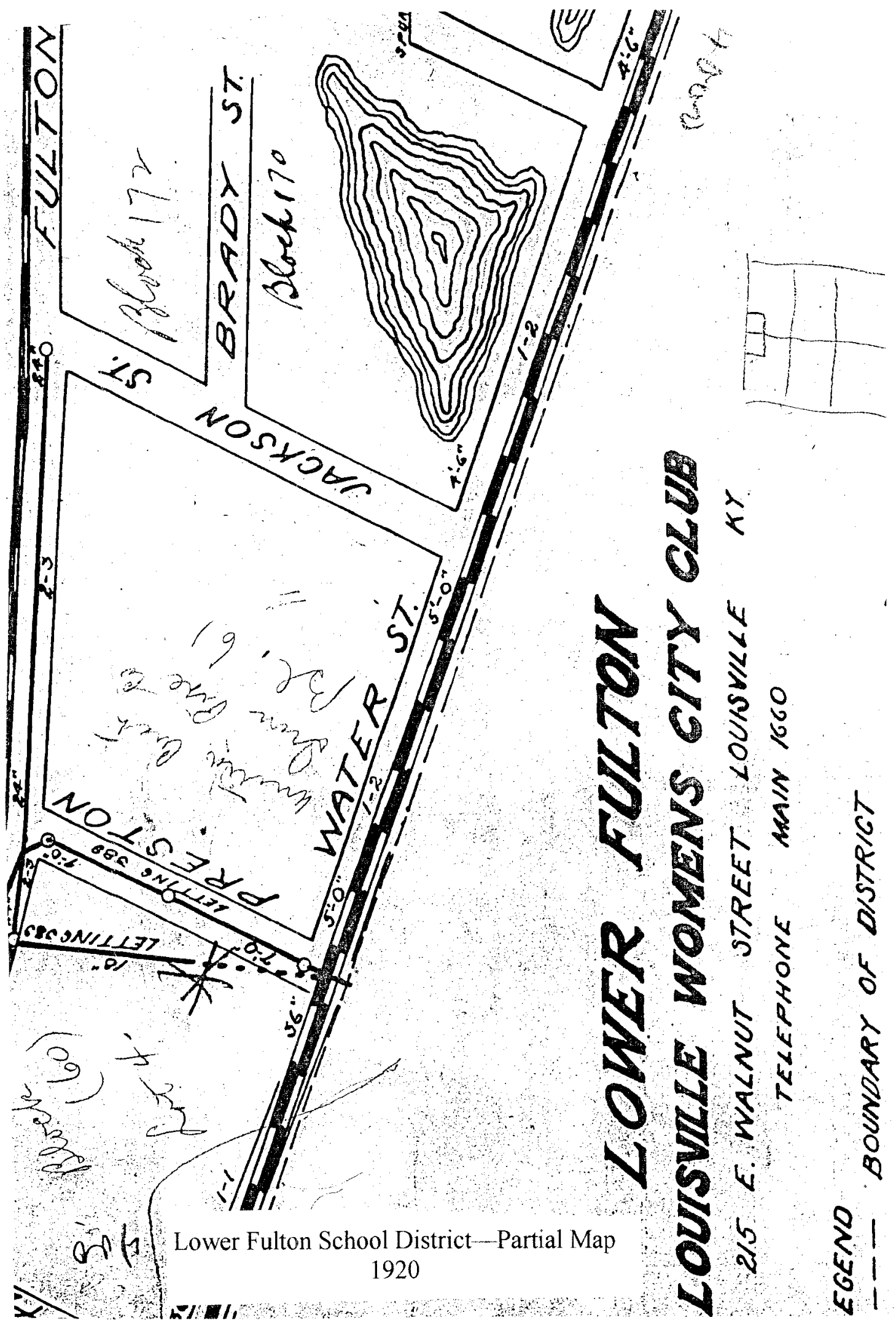




\section{LOUISVILLE WOMEN'S CITY CLUB}

HOUSING SURVEY IN RELATION TO DEATHS FROM TUBERCULOSIS-1914 TO 1923 INCLUSIVE

SURVEY BY L. C. MOREL, JUNE 1924
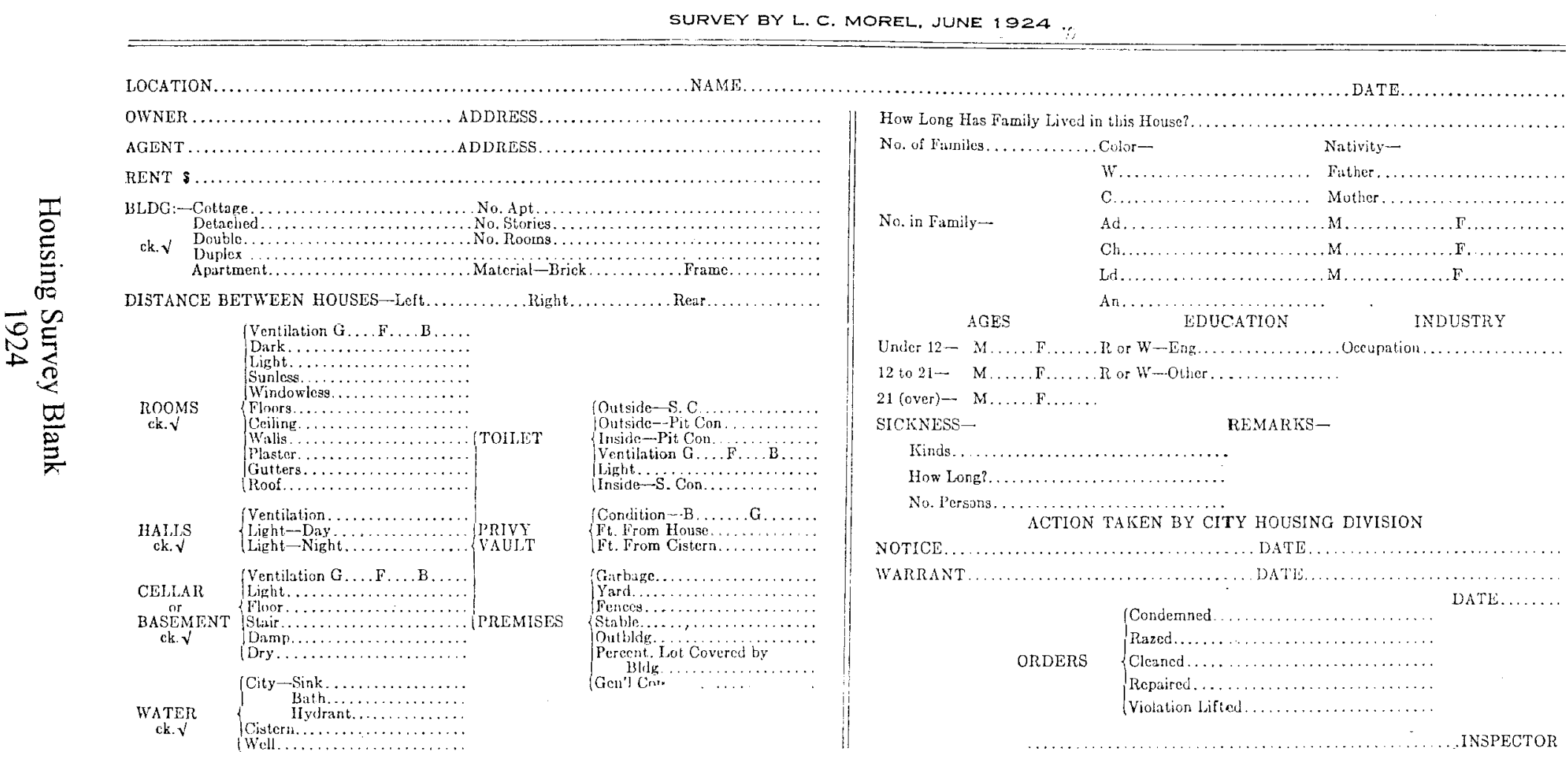


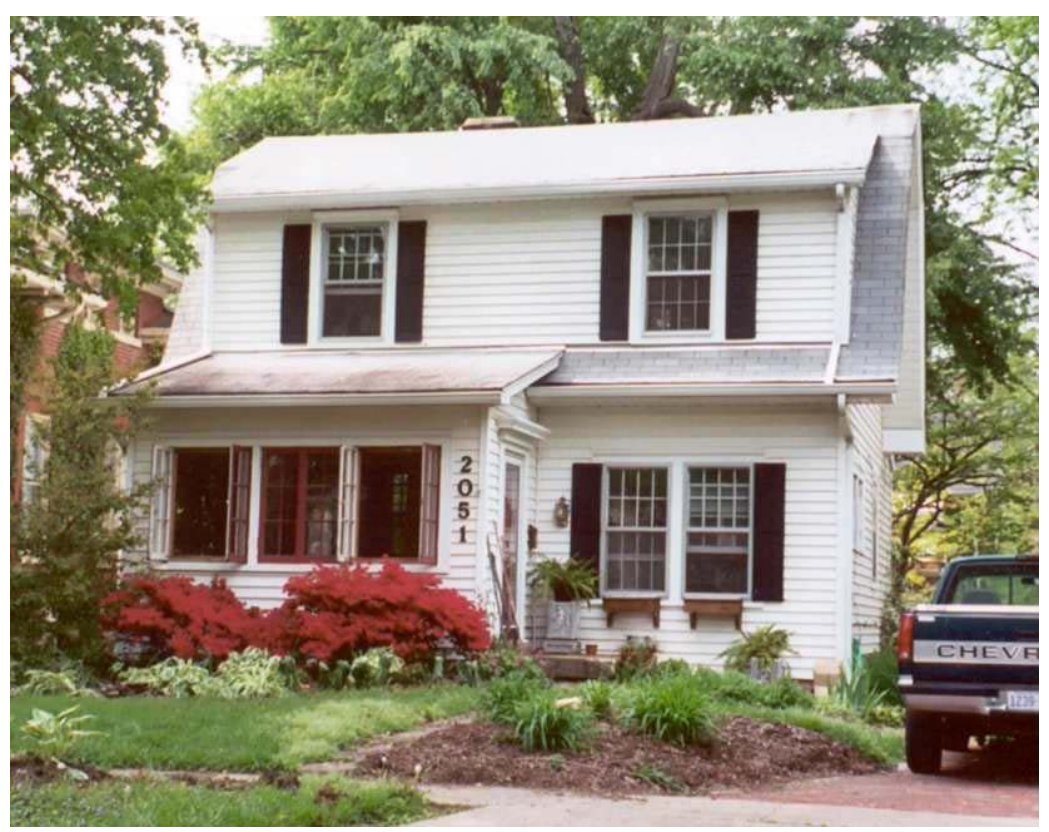

2051 Sherwood Avenue

Better Homes in America Exhibit Home and

Home of Louise Morel from 1928 through 1938 




Housing Survey Map 1934

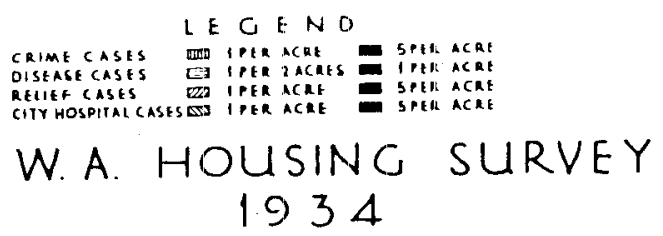

CITY PLANNING E ZONING COMMISSION LOUISYILLE KENTUICKY 


\section{CURRICULUM VITAE}

\section{Gail E. Chooljian Nall}

\section{$\underline{\text { Address }}$}

1800 Ashmoor Lane

Louisville, Kentucky 40223

502-425-0122

gechoo01@louisville.edu

\section{$\underline{\text { Education }}$}

B.A. History: Bellarmine University, May 2001, summa cum laude -Thesis: “The Kentucky Federation of Women’s Clubs: Separate Spheres, Suffrage, and Social Work

M.A. History: University of Louisville, expected December 2004 -focus in Greater Atlantic World, specializing in Women's History in the Late Nineteenth and Early Twentieth Century United States

J.D. Law: University of Louisville Brandeis School of Law, expected May 2007

\section{Positions Held/ Work Experience}

Foley, Bryant, and Holloway, Attorneys at Law

Runner, January 2004-present:

-filed pleadings and motions, office filing, some research

Filson Historical Society

Page, November 2003-September 2004:

-assisted patrons, shelved books, worked on various projects

University of Louisville, History Department

Graduate Assistant, August 2002-August 2003

-assisted Dr. Bruce Adams with encyclopedia article editing, helped with general office duties 


\section{Awards}

2002-2003: Graduate Assistantship, University of Louisville

2001-2002: Jurdem Scholarship, University of Louisville

\section{Conference Papers}

“The Kentucky Federation of Women’s Clubs: Separate Spheres, Suffrage, and Social Work”: paper presented to the Bluegrass Symposium, Spring 2002

\section{Community Activities}

Judge at National History Day Competition, University of Louisville, March 2003

\section{$\underline{\text { Academic References }}$}

Dr. Nancy Theriot

Chair, Women's and Gender Studies

University of Louisville

Louisville, Kentucky 40292

Dr. Ann Allen

Professor, History Department

University of Louisville

Louisville, Kentucky 40292

Dr. Bruce Adams

Professor, History Department

University of Louisville

Louisville, Kentucky 40292 